\title{
Regulation of GnRH pulsatility in ewes
}

\author{
Casey C Nestor ${ }^{1}$, Michelle N Bedenbaugh², Stanley M Hileman², Lique M Coolen ${ }^{3,4}$, \\ Michael N Lehman ${ }^{3}$ and Robert L Goodman ${ }^{2}$ \\ ${ }^{1}$ Department of Animal Science, North Carolina State University, Raleigh, North Carolina, USA, ${ }^{2}$ Department of \\ Physiology, Pharmacology and Neuroscience, West Virginia University, Morgantown, West Virginia, USA, \\ ${ }^{3}$ Department of Physiology and Biophysics, University of Mississippi Medical Center, Jackson, Mississippi, USA and \\ ${ }^{4}$ Department of Neurobiology and Anatomical Sciences, University of Mississippi Medical Center, Jackson, \\ Mississippi, USA
}

Correspondence should be addressed to R L Goodman; Email: rgoodman@hsc.wvu.edu

\begin{abstract}
Early work in ewes provided a wealth of information on the physiological regulation of pulsatile gonadotropin-releasing hormone $(\mathrm{GnRH})$ secretion by internal and external inputs. Identification of the neural systems involved, however, was limited by the lack of information on neural mechanisms underlying generation of $\mathrm{GnRH}$ pulses. Over the last decade, considerable evidence supported the hypothesis that a group of neurons in the arcuate nucleus that contain kisspeptin, neurokinin B and dynorphin (KNDy neurons) are responsible for synchronizing secretion of $\mathrm{GnRH}$ during each pulse in ewes. In this review, we describe our current understanding of the neural systems mediating the actions of ovarian steroids and three external inputs on GnRH pulsatility in light of the hypothesis that KNDy neurons play a key role in $\mathrm{GnRH}$ pulse generation. In breeding season adults, estradiol $\left(\mathrm{E}_{2}\right)$ and progesterone decrease GnRH pulse amplitude and frequency, respectively, by actions on KNDy neurons, with $E_{2}$ decreasing kisspeptin and progesterone increasing dynorphin release onto $\mathrm{GnRH}$ neurons. In pre-pubertal lambs, $\mathrm{E}_{2}$ inhibits $\mathrm{GnRH}$ pulse frequency by decreasing kisspeptin and increasing dynorphin release, actions that wane as the lamb matures to allow increased pulsatile GnRH secretion at puberty. Less is known about mediators of undernutrition and stress, although some evidence implicates kisspeptin and dynorphin, respectively, in the inhibition of $\mathrm{GnRH}$ pulse frequency by these factors. During the anoestrus, inhibitory photoperiod acting via melatonin activates A15 dopaminergic neurons that innervate KNDy neurons; $E_{2}$ increases dopamine release from these neurons to inhibit KNDy neurons and suppress the frequency of kisspeptin and $\mathrm{GnRH}$ release.

Reproduction (2018) 156 R83-R99
\end{abstract}

\section{Introduction}

It is now generally recognized that the episodic nature of gonadotropin-releasing hormone $(\mathrm{GnRH})$ secretion is a key characteristic of hypothalamic control of reproductive function. Episodic release of $\mathrm{GnRH}$ was first inferred from the pulsatile pattern of luteinizing hormone (LH) concentrations in ovariectomized (OVX) rhesus monkeys (Dierschke et al. 1970), a pattern that has since been observed in many species under a large variety of endocrine conditions (Karsch 1987). Subsequent measurements of GnRH concentrations in the hypophyseal portal blood of ewes have demonstrated that this pattern of secretion consists of relative brief (about 5 min long) bouts of $\mathrm{GnRH}$ secretion followed by prolonged (ranging from $30 \mathrm{~min}$ to several hours depending on the endocrine status of the animal) periods when no secretion occurs (Clarke \& Cummins 1982, Moenter et al. 1992b). The one exception to this episodic pattern occurs during the preovulatory $\mathrm{GnRH} /$ LH surge that occurs late in the follicular phase of the ovarian cycle; although acute fluctuations in $\mathrm{GnRH}$ levels (Clarke 1993, Evans et al. 1995b) have led some to suggest that pulsatile GnRH secretion occurs during the surge (Clarke 1995), it is clear that no prolonged hiatus in $\mathrm{GnRH}$ release, similar to that seen during classical episodic secretion, occurs during the GnRH surge (Moenter et al. 1992a, Clarke 1993). Moreover, episodic and surge secretions are controlled by different neural networks and feedback actions of ovarian steroids. It is generally accepted in rodents that different neural networks are involved; for example, arcuate kisspeptin neurons participate in the control of $\mathrm{GnRH}$ pulses, while the more rostral kisspeptin population mediates the estrogen-induced GnRH surge (Dungan et al. 2006). In ewes, arcuate kisspeptin neurons participate in the control of both episodic and surge secretion (Smith et al. 2009, Merkley et al. 2012), while the more rostral kisspeptin population is only involved in the surge (Merkley et al. 2012, Ezzat et al. 2015). In these (and other) species, GnRH pulses are controlled by the negative feedback actions of both estradiol $\left(E_{2}\right)$ 
and progesterone, while the GnRH surge is triggered by the positive feedback action of high $E_{2}$ concentrations at the end of the follicular phase of the ovarian cycle. This review will focus on episodic $\mathrm{GnRH}$ secretion in ewes that occurs at other times of the estrous cycle.

The critical importance of pulsatile $\mathrm{GnRH}$ secretion was demonstrated in a classic paper (published 40 years ago) which reported that $\mathrm{LH}$ and FSH concentrations in OVX monkeys could be maintained with episodic, but not continuous, administration of exogenous GnRH (Belchetz et al. 1978). This observation, which has since been confirmed in several other species (Chakraborty et al. 1974, Marshall \& Kelch 1986, Blum et al. 2000), led to the extensive use of longacting $\mathrm{GnRH}$ agonists in clinical reproductive medicine. Contemporaneous studies also indicated that changes in $\mathrm{GnRH}$ pulse patterns play a major role in timing the events of the ovarian cycle (Goodman \& Karsch 1981) and are key determinants of fertility during the pubertal transition (Wildt et al. 1980, Ojeda et al. 1983, Foster et al. 1984) and annually in seasonal breeders (Karsch et al. 1980). Thus, the importance of episodic GnRH secretion to the neuroendocrine control of reproduction has been established for several decades. Despite this importance, the neural mechanisms responsible for the synchronization of GnRH secretory activity necessary for episodic release remained a 'black box' commonly referred to as the 'GnRH pulse generator' until the last 10 years. Starting in 2007, several lines of evidence have supported the hypothesis that a group of neurons in the arcuate nucleus (ARC) of the hypothalamus containing kisspeptin, the tachykinin, neurokinin $\mathrm{B}(\mathrm{NKB})$ and the endogenous opioid peptide (EOP), dynorphin (termed KNDy neurons), are responsible for the generation of GnRH pulses (Navarro et al. 2009, Lehman et al. 2010, Rance et al. 2010, Okamura et al. 2013).

Studies in ewes have made major contributions to our understanding of the physiological importance of changes in GnRH pulse patterns, the control of these patterns by the inhibitory actions of estradiol and progesterone, and the role of KNDy neurons in pulse generation for two major reasons. First, because sheep have a large blood volume and adapt readily to handling, they are ideally suited for the frequent blood sampling necessary to characterize pulsatile LH secretion under a variety of conditions. More importantly, sheep are the only species in which $\mathrm{GnRH}$ concentrations in hypophyseal portal blood samples can be monitored for long periods of time in unanesthetized, unstressed animals (Clarke \& Cummins 1982, Caraty \& Locatelli 1988). Such studies have provided direct evidence of the effects of internal (e.g., ovarian steroids (Clarke et al. 1987, Evans et al. 1995a)) and external (e.g., stressors) (Battaglia et al. 1997, Wagenmaker et al. 2009) factors on $\mathrm{GnRH}$ secretion, and the best characterization of secretory dynamics of $\mathrm{GnRH}$ secretion during each pulse (Moenter et al. 1992b). Moreover, KNDy neurons were first identified in ewes (Goodman et al. 2007), and this animal model has provided critical experimental evidence supporting the role of KNDy neurons in $\mathrm{GnRH}$ pulse generation. Therefore, this review will focus largely on studies in ewes on the control of pulsatile $\mathrm{GnRH}$ secretion. We will first briefly describe the current model for $\mathrm{GnRH}$ pulse generation, including current unresolved questions. We will then consider the physiological regulation of $\mathrm{GnRH}$ pulsatility in sheep under a variety of conditions; in each section, we will summarize earlier studies on this regulation and then discuss our current understanding of the underlying neural mechanisms in the context of the KNDy model for $\mathrm{GnRH}$ pulse generation.

\section{The role of KNDy neurons in GnRH pulse generation in sheep}

The KNDy model of pulse generation was developed based on several key anatomical characteristics of KNDy neurons in the ovine ARC: (1) as noted earlier, they contain two stimulatory (kisspeptin and NKB) peptides, both of which are critical for fertility in humans (de Roux et al. 2003, Seminara et al. 2003, Topaloglu et al. 2009), and one inhibitory (dynorphin) peptide (Goodman et al. 2004); 2) they form an extensive inter-connected network (Foradori et al. 2006); 3) they contain receptors for NKB (NK3R) (Amstalden et al. 2010), but not for kisspeptin (Kiss1r) (Smith et al. 2011) and 4) based on triple-labeled immunohistochemical analysis using unique markers for KNDy neurons, they project to $45 \%$ of the $\mathrm{GnRH}$ cell bodies in the preoptic area (POA) and to $60 \%$ of mediobasal hypothalamus (MBH) GnRH neurons (Merkley et al. 2015). It should be noted that projections from neurons in the ARC to POA GnRH cells were not observed in two ewes using anterograde tract tracers (Pompolo et al. 2001), but this could reflect the limited number of cells bodies labeled with such tracers (Goodman et al. 2018). Moreover, retrograde tract tracing studies indicate that dynorphin-ir neurons in the ARC project to the region of the POA containing GnRH cell bodies (Dufourny et al. 2005). In its simplest form, the KNDy model for GnRH pulse generation (Navarro et al. 2009, Lehman et al. 2010, Goodman \& Inskeep 2015) proposes that kisspeptin is the output of the KNDy network that drives $\mathrm{GnRH}$ secretion during a pulse, while NKB and dynorphin act within this network to initiate and terminate each GnRH pulse, respectively (Fig. 1). At the start of a pulse, initial release of NKB triggers a positive feedback loop that rapidly increases KNDy neural activity, kisspeptin release and thus $\mathrm{GnRH}$ secretion. Within minutes, dynorphin release begins to hold KNDy neural activity in check and, after about 5 min, terminates kisspeptin release and the $\mathrm{GnRH}$ pulse. 


\section{Pulse onset: NKB (via NK3R) and kisspeptin}
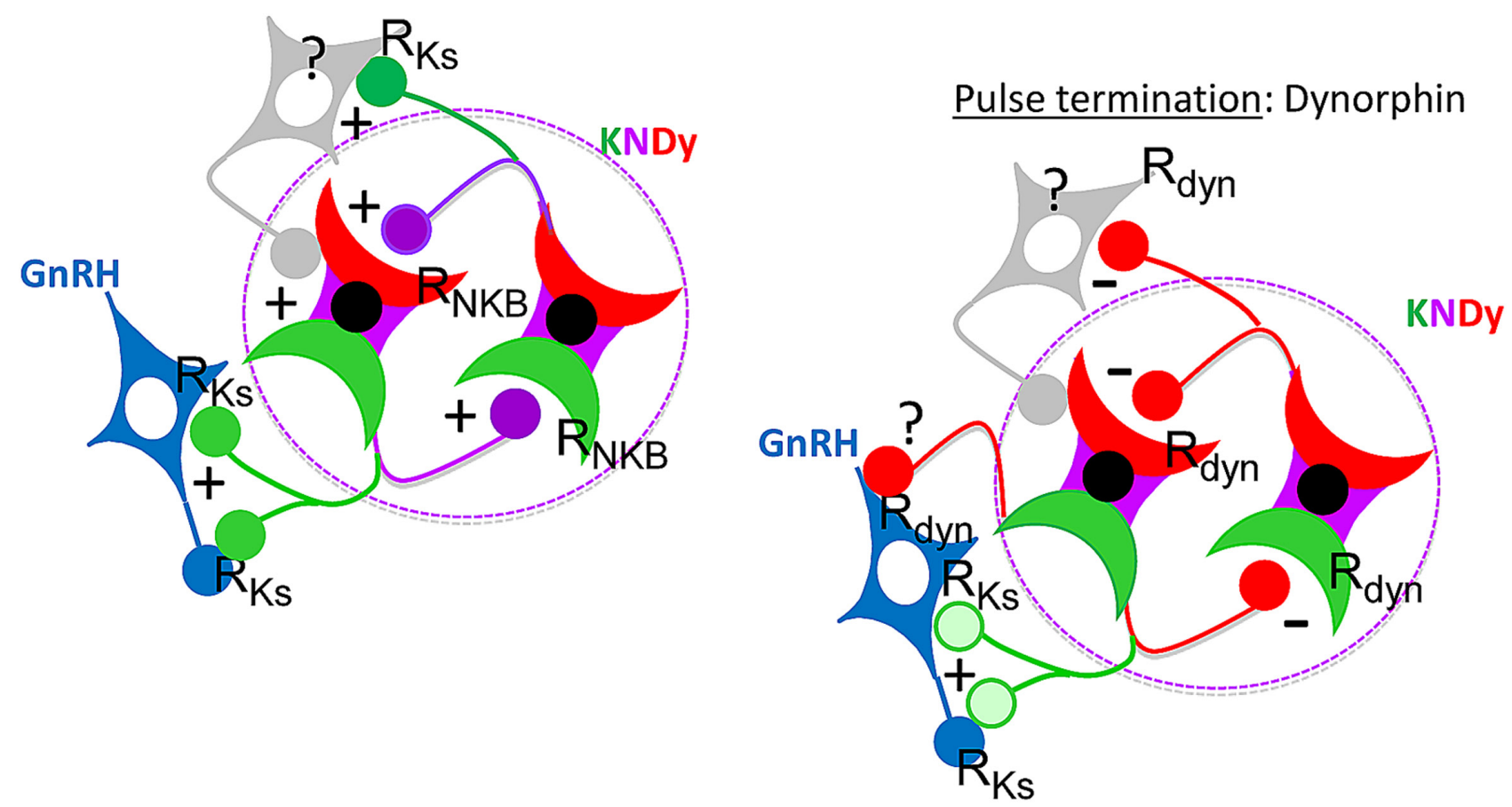

Figure 1 Model for control of KNDy neural activity proposed to drive episodic GnRH secretion. Each GnRH pulse is initiated by NKB (purple) acting within the KNDy network (within dashed oval), which stimulates kisspeptin (green) release to drive GnRH (blue) secretion and activate unidentified KISS1R-containing ARC neurons (gray) that reinforces the stimulatory actions of NKB on KNDy neurons. GnRH release is then terminated by dynorphin (red) release from KNDy neurons acting either directly on KNDy neurons and/or GnRH neurons and/or the unidentified KISS1R-containing neurons. $R_{\mathrm{dyn} n^{\prime}}$ kappa-opioid receptor; $\mathrm{R}_{\mathrm{Ks}}$ KISS1R; $\mathrm{R}_{\mathrm{NKB}}$, NK3R. Note that the color in each terminal indicates the biologically active transmitter (possibly due to selective expression of post-synaptic receptors) and does not reflect selective transport of that peptide to the terminal. Redrawn from Lehman et al. (8) with permission from the Endocrine Society.

Because several recent reviews are available describing the development of, and experimental support for, this model in detail (Okamura et al. 2013, Goodman et al. 2014, Goodman et al. 2015), we will briefly summarize evidence for it in sheep. First, as mentioned earlier and discussed in more detail later, the cellular location of receptors for KNDy peptides (Fig. 2) is consistent with the proposed actions of each peptide. Second, the ability of i.v. naloxone (a non-specific antagonist to EOP receptors) to increase the amplitude and duration of $\mathrm{GnRH}$ release during pulses indicates a role for an EOP in termination of each $\mathrm{GnRH}$ pulse (Goodman et al. 1995). Third, ARC microimplants of NKB and a NK3R antagonist increased and decreased LH pulse frequency, respectively, while ARC microimplants of a K-EOP receptor (KOR) antagonist increased $\mathrm{LH}$ pulse frequency in OVX ewes (Goodman et al. 2013). Finally, assessment of KOR internalization as an index of dynorphin release indicated that dynorphin release begins shortly after the start of a pulse and is still evident toward the end of GnRH secretion (Weems et al. 2016a, 2017b). This working model has also received substantial experimental support from studies examining bursts in multi-unit activity associated with LH pulses in goats (Wakabayashi et al. 2010, Okamura et al. 2013) and evidence in a number of species that the stimulatory actions of NKB on LH secretion are mediated by kisspeptin released from KNDy neurons (Navarro et al. 2011a,b, Ramaswamy et al. 2011, Grachev et al. 2012).

Although there is now strong evidence that KNDy neural activity is necessary for episodic GnRH secretion in ewes, several unresolved issues remain. First, it is unclear whether episodic kisspeptin release drives GnRH pulses or if kisspeptin is simply permissive for episodic GnRH secretion in ewes. There is direct evidence in monkeys for episodic kisspeptin release in the MBH (Keen et al. 2008) and in mice for episodic activation of KNDy neurons just before the onset of each LH pulse (Clarkson et al. 2017). In ewes, Fos expression (a commonly used marker for neural activity) increases in KNDy neurons 30 min after an endogenous LH pulse (Ezzatetal. 2015), but there is no direct evidence coupling this to episodic kisspeptin release. In the absence of such data, several studies have examined the response of $\mathrm{LH}$ (and one study of $\mathrm{GnRH}$ ) to continuous kisspeptin infusions to indirectly address this issue. Initial work demonstrated that prolonged infusions of kisspeptin were unable to maintain elevated $\mathrm{LH}$ concentrations so 

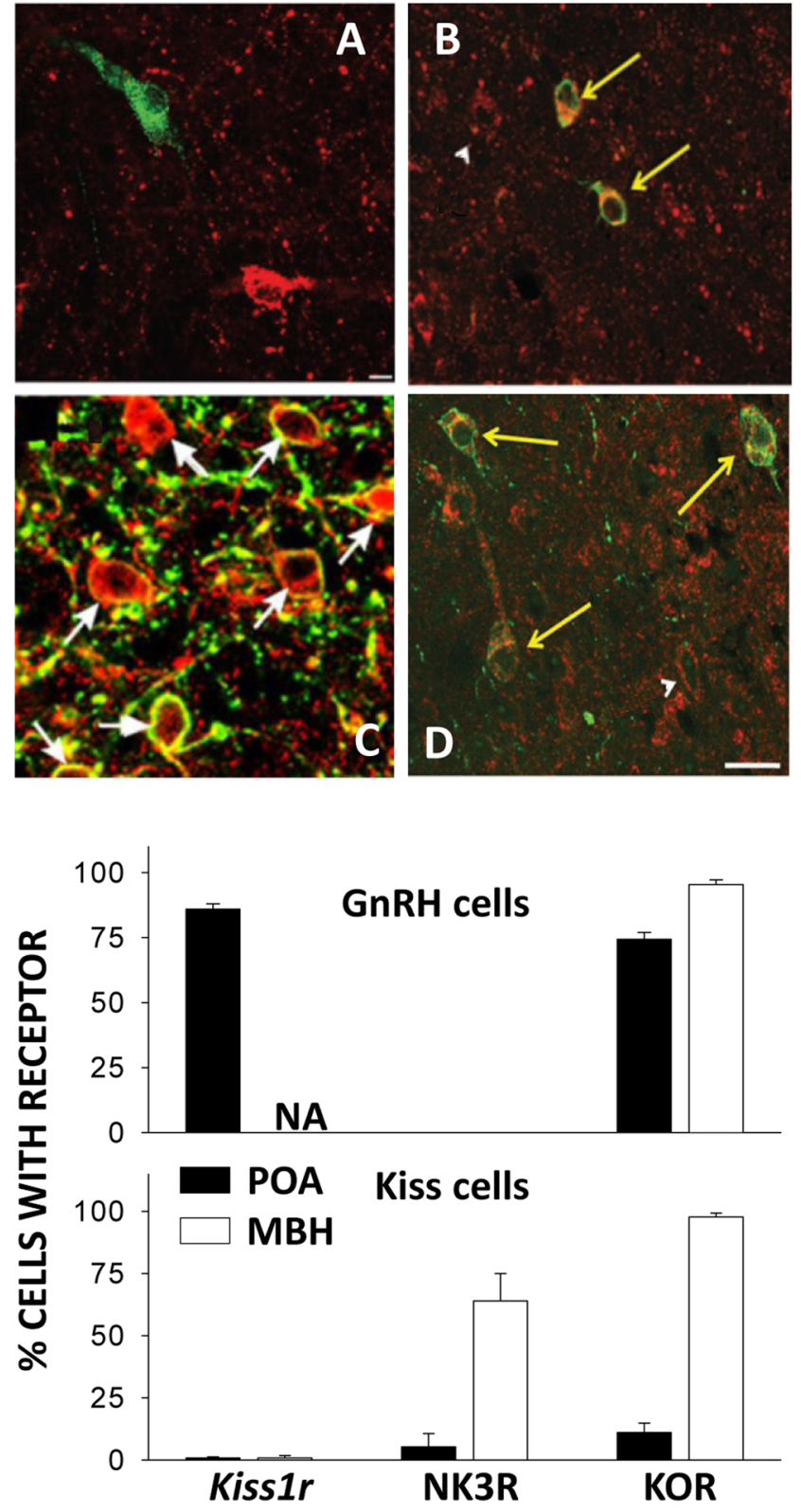

Figure 2 Receptors for KNDy peptides in GnRH and kisspeptin neurons. Top four panels depict dual ICC for NK3R (red in A, green in C) and KOR (red in B and D) in GnRH neurons (green in A and B) and kisspeptin neurons (red in C, green in D). Arrows identify dual labeled cells, arrowheads indicate single labeled KOR neurons. Bottom panels present the mean ( \pm S.E.M.) percentage of GnRH and kisspeptin cells in the POA and MBH (KNDy cells for latter) containing each receptor. Note no GnRH cells contained NK3R. NA, not analyzed. Photomicrographs in panels $A$ and $C$ reprinted from Amstalden et al. (2010) and Ahn et al., J Neuroendocrinol 27: 100-110, 2015, respectively with permission from the British Society for Neuroendocrinology. Photomicrographs in panels B and D reprinted from Weems et al. $(2016 a, b)$, with permission from the Endocrine Society. Bar graphs in bottom panel are based on data from these three references (NK3R and KOR) and from Smith et al. (2011) (Kiss1r). that there was no difference between treated and control ewes after 2 days of infusion (Caraty et al. 2007). This, and similar data in monkeys (Ramaswamy et al. 2007), was interpreted to mean that episodic kisspeptin release is needed for episodic GnRH secretion. More recently, two studies examined this question in a more acute time frame (3-6h), but reached opposite conclusions. In one study, kisspeptin infusions were able to maintain LH pulses during inhibition of episodic $\mathrm{LH}$ secretion with an NK3R antagonist in OVX ewes (Clarke et al. 2018). In the other, kisspeptin infusions produced prolonged continuous elevations in both $\mathrm{GnRH}$ and $\mathrm{LH}$ secretion in anoestrous ewes, whereas a bolus kisspeptin injection produced a GnRH and LH pulse (Caraty et al. 2013). The most likely explanation for the different LH responses in these two studies is the method used to eliminate endogenous GnRH pulses. The latter study used anestrous ewes, in which KNDy neural activity is strongly inhibited (see below), while the former used an NK3R antagonist to inhibit this neural network. It is possible that the NK3R antagonist did not completely abolish KNDy neural activity in these OVX ewes, particularly, since small increments in $\mathrm{LH}$, which did not reach the limit of detection of the pulse analysis used, are evident is some individual ewes in this report. If so, the small residual activity of these neurons on $\mathrm{GnRH}$ release might have been amplified by the kisspeptin infusion. Overall, the preponderance of the kisspeptin infusion and Fos data (Ezzat et al. 2015) support an episodic release of kisspeptin in ewes, but more direct evidence is needed to resolve this issue.

Another important question involves the specific neurons on which KNDy peptides act to control GnRH secretion during a pulse. The fact that NKB acts on KNDy neurons seems clear because most ovine KNDy neurons, but no GnRH neurons, contain NK3R (Fig. 2) (Amstalden et al. 2010). Similarly, kisspeptin specifically acts on GnRH neurons because Kiss $1 r$ is found in $\mathrm{GnRH}$, but not KNDy, neurons in ewes (Smith et al. 2011). However, Kiss1r is found in non-KNDy neurons in the ovine ARC (Smith et al. 2011) and local administration of a KISS1R antagonist produces a modest reduction of LH pulse frequency in OVX ewes (Goodman et al. 2013). Thus, it is possible that kisspeptin actions within the ARC via non-KNDy neurons contribute to episodic GnRH secretion. In contrast to NK3R and Kiss $1 r$, KOR is found in both KNDy and GnRH neurons (Weems et al. 2016b) so dynorphin could act on either (or both) cell type to terminate GnRH secretion. As noted earlier, based on internalization of KOR, dynorphin appears to act on KNDy neurons throughout most of a pulse. Interestingly, KOR internalization was also observed in $\mathrm{MBH}$ GnRH neurons but only at the end of a pulse (Weems et al. 2017b). No internalization of KOR was observed in POA GnRH neurons, which is consistent with earlier 
evidence that $\mathrm{MBH} \mathrm{GnRH}$ neurons drive episodic $\mathrm{LH}$ secretion (Boukhliq et al. 1999). Thus, dynorphin actions on KNDy neurons likely hold GnRH secretion in check during a pulse, and its actions on both KNDy and GnRH neurons contribute to pulse termination.

\section{Control of pubertal GnRH/LH secretion through KNDy neurons}

In the ewe, puberty onset is heralded by an increase in pulsatile $\mathrm{GnRH} / \mathrm{LH}$ secretion, evident as an increase in LH pulse frequency during the 12 days before the first ovulation (Huffman et al. 1987). A large body of evidence indicates that the pre-pubertal hiatus in $\mathrm{GnRH} /$ $\mathrm{LH}$ secretion is due to the strong inhibitory actions of $E_{2}$ (Foster \& Hileman 2015). Thus, removal of steroidnegative feedback by OVX in the pre-pubertal ewe lamb results in an elevation of $\mathrm{GnRH} / \mathrm{LH}$ secretion, which can readily be reduced with subcutaneous administration of $\mathrm{E}_{2}\left(\mathrm{OVX}+\mathrm{E}\right.$ lambs). This $\mathrm{E}_{2}$-induced suppression reflects an inhibition of $\mathrm{GnRH} / \mathrm{LH}$ pulse frequency that persists until the time when puberty onset would normally occur (Foster \& Hileman 2015). Many other species (e.g., cattle, guinea pigs and ferrets) share a similar mechanism for control of puberty onset; however, in primates, the gonadostat hypothesis does not apply to the entirety of the pre-pubertal period, but does arise during the peri-pubertal period between menarche and the first ovulation (Goodman 2015). Since circulating levels of $E_{2}$ remain constant in this steroid-clamp model, it is the sensitivity to the inhibitory actions of $E_{2}$ in the hypothalamus that lessens as the animal matures and allows for the elevation in episodic $\mathrm{GnRH} / \mathrm{LH}$ secretion necessary for first ovulation (commonly referred to as the gonadostat hypothesis (Foster \& Hileman 2015)). While GnRH neurons are the final common output from the central nervous system controlling gonadotropin release from the anterior pituitary, these neurons in the ewe do not express estrogen receptor- $\alpha$ (Herbison et al. 1993, Lehman \& Karsch 1993), the receptor thought to mediate the negative feedback of $E_{2}$. Therefore, the neural pathways regulating puberty onset in the ewe must lie upstream of $\mathrm{GnRH}$ neurons.

In humans (de Roux et al. 2003, Seminara et al. 2003, Topaloglu et al. 2012) and mice (Seminara et al. 2003, d'Anglemont de Tassigny et al. 2007), disruption of kisspeptin signaling results in blockade of pubertal development. Although similar mutations have not been found in sheep, there is strong support in ewes for the idea that kisspeptin acts as a gatekeeper to puberty onset. Hourly administration of kisspeptin to pre-pubertal ewe lambs acutely stimulated episodic $\mathrm{LH}$ secretion and prolonged hourly treatment induced an LH surge and ovulation (Redmond et al. 2011b). Thus, any central signaling components between kisspeptin and $\mathrm{GnRH}$ neurons that are needed for normal $\mathrm{GnRH}$ secretion appear to be intact and waiting for the stimulatory kisspeptin drive prior to puberty. ARC kisspeptin expression in the pre-pubertal ewe is substantially reduced by even low levels of circulating $E_{2}$ in gonadintact (Nestor et al. 2012) or OVX+E (Lopez et al. 2016) lambs compared to OVX lambs. Furthermore, the elevation in $\mathrm{LH}$ secretion that occurs around the time of puberty in the ewe is closely mirrored by an increase in both ARC kisspeptin mRNA expression in $\mathrm{OVX}+\mathrm{E}_{2}$ ewes (Redmond et al. 2011a) and kisspeptin protein expression in gonad-intact ewes (Nestor et al. 2012, Polkowska et al. 2017). There is also an increase in the percentage of POA GnRH neurons that receive kisspeptin input that parallels the change in ARC kisspeptin cell numbers during this period (Nestor et al. 2012). Taken together, these data indicate that the increase in pulsatile secretion of $\mathrm{GnRH} / \mathrm{LH}$ secretion responsible for puberty onset in the ewe is dependent on an increase in signaling by ARC kisspeptin neurons.

Similar to kisspeptin signaling, NKB is critical for pubertal development in humans (Topaloglu et al. 2009, Gianetti et al. 2010), and there is some evidence that it may stimulate $\mathrm{GnRH} / \mathrm{LH}$ secretion during ovine puberty onset. In ewe lambs the NK3R agonist, senktide, stimulated LH secretion prior to puberty onset (Nestor et al. 2012). NKB expression is also inhibited by the ovary, presumably via $E_{2}$ secretion, prior to puberty since the number of NKB-immunoreactive (ir) neurons in the ARC increased following OVX in pre-pubertal lambs. (Nestor et al. 2012). However, a similar OVXinduced increase in NKB expression was also seen in post-pubertal lambs, suggesting that this action of $E_{2}$ may not change during puberty. Although the number of NKB-ir soma did not change following puberty onset in ovary-intact lambs, we did observe an increase in NKB-ir fiber density in the ARC and suggest that this translates to an increase in NKB activity in post-pubertal lambs (Nestor et al. 2012). Thus, although this correlational evidence indicates that increases in NKB contribute to puberty onset in ewes, further work is needed to adequately test this hypothesis. For example, it would be important to determine if there are increases in NKB input to key reproductive neurons $(\mathrm{GnRH}$, kisspeptin, etc.) during puberty and if disruption of NKB signaling delays puberty onset in the ewe lamb.

While kisspeptin and NKB are stimulatory, the third peptide in KNDy neurons, dynorphin, has an inhibitory effect on $\mathrm{GnRH} / \mathrm{LH}$ secretion. Dynorphin signaling in the adult ewe is known to mediate progesterone-negative feedback on GnRH/LH secretion (Goodman et al. 2004, Foradori et al. 2005), and there is now growing evidence that this EOP may be part of the 'brake' restraining GnRH/ $\mathrm{LH}$ release prior to puberty in sheep. $\mathrm{GnRH}$ neurons in the pre-pubertal ewe lamb express KOR, but dynorphin-ir is not detectable in lambs, although it is readily seen in tissue from adult luteal phase ewes (Lopez et al. 2016). Despite this lack of evidence for detectable dynorphin protein expression in lambs, infusion of nor-BNI, a KOR 
antagonist, into the lateral ventricle of OVX $+E$ lambs at a pre-pubertal age increased LH pulse frequency, but failed to do so in the same lambs at a post-pubertal age (Fig. 3). However, it is unclear where dynorphin acts to hold LH in check in pre-pubertal lambs because nor$\mathrm{BNI}$ had no effect on $\mathrm{LH}$ secretion when administered into the POA alone or the ARC alone (Fig. 3). The two most likely explanations for the differences in effects of nor-BNI in pre-pubertal lambs are 1) dynorphin action in either the POA or ARC is sufficient to suppress $\mathrm{GnRH} /$ $\mathrm{LH}$ secretion, or 2) dynorphin acts outside of the POA and $\mathrm{ARC}$ to inhibit $\mathrm{GnRH} / \mathrm{LH}$ secretion.

While the negative feedback action of $\mathrm{E}_{2}$ is the primary internal signal holding GnRH pulse frequency in check prior to puberty, energy intake is a critical external signal necessary for normal pubertal development. A clear example of this is seen in pre-pubertal ewes where undernutrition to the point of growth restriction delays puberty onset (Fitzgerald et al. 1982, Foster \& Olster 1985, Prasad et al. 1993). This effect of food restriction reflects an inhibition of LH pulse frequency and does
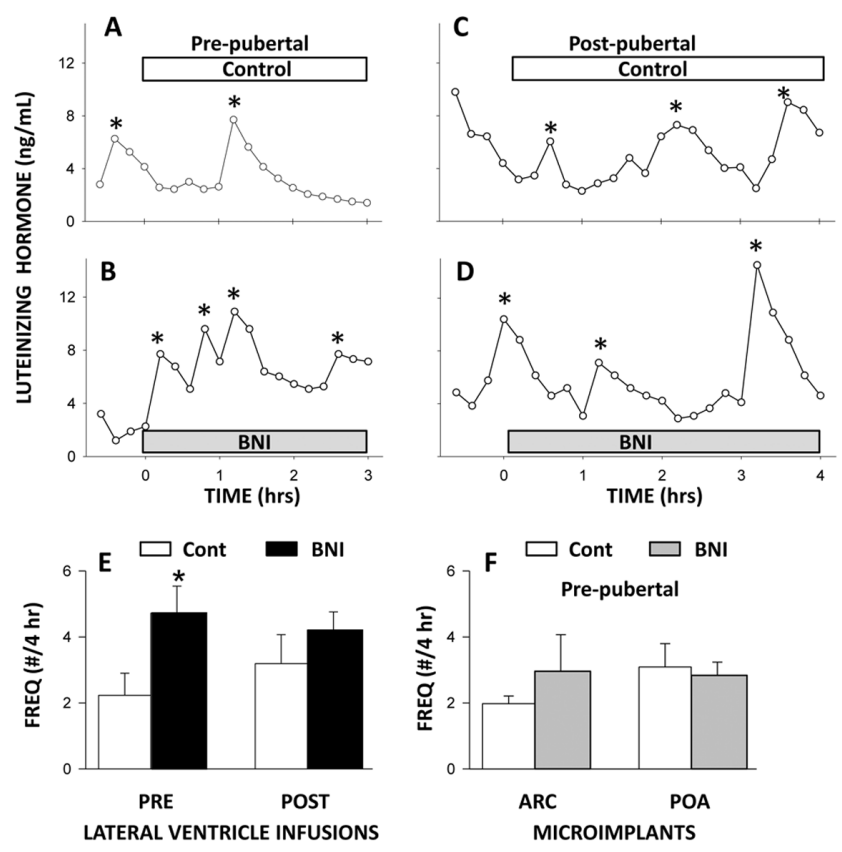

Figure 3 Effect of a KOR antagonist on LH pulse frequency in preand post-pubertal lambs. Top panels: LH pulse patterns in response to lateral ventricle infusions of vehicle (Control) or a KOR antagonist (BNI) in OVX +E pre-pubertal (panels A and B) and post-pubertal (panels $\mathrm{C}$ and D) lambs. *Peak of LH pulse. Bottom panels: mean $( \pm$ S.E.M.) LH pulse frequency in response to lateral ventricle infusions of vehicle (Cont) or the KOR antagonist (BNI) in estrogen-treated OVX pre- and post-pubertal lambs are shown on left (panel E). Effect of empty (Cont) or BNI-filled microimplants in the ARC or POA of ovary-intact pre-pubertal lambs on pulse frequency are depicted on right (panel F). ${ }^{*} P<0.05$ vs Cont. Data on lateral ventricle infusions redrawn from Lopez et al. (2016) with permission from the British Society for Neuroendocrinology. Data on the effects of microimplants have not been published. not require $E_{2}$ because it is evident in OVX lambs (Foster \& Olster 1985), although food restriction does also increase the response of the $\mathrm{MBH}$ to the inhibitory actions of $E_{2}$ (McManus et al. 2005). Subsequent work clearly demonstrated that the inhibitory actions of food restriction in OVX lambs reflects a central suppression of GnRH release from the hypothalamus (Ebling et al. 1990, Prasad et al. 1993, I'Anson et al. 2000), but the neural mechanisms by which energy balance regulates $\mathrm{GnRH} / \mathrm{LH}$ secretion in ewe lambs still remain largely unknown. Early work focused on the possible role of the EOP, $\beta$-endorphin, and neuropeptide Y (NPY) because both inhibited LH secretion in sheep (McShane et al. 1992, Prasad et al. 1993), probably via mu-opioid receptors (Weems et al. 2018) and Y2 receptors (Barker-Gibb et al. 1995), respectively. Chronic food restriction of ewe lambs increased mRNA encoding NPY in the ARC (McShane et al. 1993), but did not alter NPY release in the median eminence (Prasad et al. 1993). In contrast, food restriction decreased both the mRNA encoding $\beta$-endorphin and the release of this EOP into the median eminence (McShane et al. 1993, Prasad et al. 1993). However, the relevance of these changes to the inhibition of $\mathrm{GnRH}$ release by food restriction is unclear because, as noted earlier, $\beta$-endorphin inhibits GnRH secretion (Prasad et al. 1993) and naloxone has no effect on LH secretion in food-restricted lambs (Ebling et al. 1990).

Considerable effort has been spent trying to identify the peripheral signal(s) controlled by changes in nutritional intake that contribute to the inhibition of GnRH secretion (Foster \& Hileman 2015), with a large body of work focused on the adipose-produced hormone leptin. Most of this work has been done in adult ewes, but one study in gonadectomized lambs reported that leptin concentrations fall with fasting and that exogenous leptin can restore the fasting-induced decrease in LH pulse frequency seen in these animals (Nagatani et al. 2000). However, this work was done in castrated ram lambs and the sexes may differ in their response to food restriction (Foster \& Hileman 2015). In light of the role of kisspeptin in puberty onset in many species, the recent focus of studies on food restriction in the ewe lamb has started to shift to the role of this peptide. One study demonstrated that 2 months of food restriction reduced hypothalamic kisspeptin mRNA expression (Wang et al. 2016) and another found that a short-term (3-day) fast in peri-pubertal ewe lambs reduced kisspeptin protein expression in the POA and ARC (Polkowska et al. 2015). Thus, studies of the neural mechanisms by which undernutrition inhibits $\mathrm{GnRH}$ secretion in lambs are in their early stages and further work is needed to determine the effects of nutrition on NKB and dynorphin expression and the functional roles of all three KNDy peptides in the changes in $\mathrm{GnRH}$ pulsatility during times of altered nutritional balance. 


\section{Negative feedback control of $\mathrm{GnRH}$ pulsatility during the ovine estrous cycle}

When considering the negative feedback control of pulsatile $\mathrm{GnRH}$ secretion in ewes, it is important to distinguish between the breeding season, when regular 16- to 17-day oestrous cycles occur, and the nonbreeding season, when ewes are anovulatory, because there are marked seasonal differences in the actions of $E_{2}$ on GnRH pulses (Legan et al. 1977, Goodman \& Inskeep 2015); these will be discussed in the next section. There are two major negative feedback actions of progesterone and $E_{2}$ on $\mathrm{GnRH}$ pulses during the ovine oestrous cycle: progesterone inhibits $\mathrm{GnRH}$ pulse frequency and $E_{2}$ inhibits GnRH pulse amplitude (Evans et al. 1995a, Goodman et al. 2002). These actions, which account for the changes in $\mathrm{GnRH}$ and $\mathrm{LH}$ pulse patterns observed in the luteal and follicular phases, were first inferred from LH pulse patterns in jugular blood and have since been confirmed by measurements of $\mathrm{GnRH}$ in hypophyseal portal blood (Clarke et al. 1987). Estradiol also increases GnRH pulse frequency, alters the shape of $\mathrm{GnRH}$ pulses and increases $\mathrm{GnRH}$ secretion between pulses (Evans et al. 1995a, Goodman et al. 2002). However, since these changes occur with $E_{2}$ levels that induce a $\mathrm{GnRH} / \mathrm{LH}$ surge, but not basal $\mathrm{E}_{2}$ concentrations, they most likely reflect the positive feedback actions of this steroid. Moreover, there is very little information on the underlying neural mechanisms (Goodman et al. 2002), and no data on relevant changes in KNDy neurons that could account for these three actions of $E_{2}$ on pulsatile $\mathrm{GnRH}$ secretion. Therefore, we will focus on the negative feedback actions of progesterone and $E_{2}$ on $\mathrm{GnRH}$ pulse frequency and amplitude.

There is now considerable evidence that progesteronenegative feedback is mediated, at least in part, by dynorphin release from KNDy neurons onto $\mathrm{MBH} \mathrm{GnRH}$ neurons. Early data that led to this hypothesis has been reviewed (Goodman et al. 2002) and includes evidence that (1) knife cuts between the POA and $\mathrm{MBH}$ did not affect progesterone-negative feedback (Whisnant \& Goodman 1994) indicting that the MBH contains all the neural elements sufficient for this action of progesterone; (2) relatively non-selective antagonists to EOP receptors increased $\mathrm{LH}$ pulse frequency in luteal phase ewes and in OVX ewes treated with progesterone, but not in untreated OVX animals (Whisnant \& Goodman 1988, Yang et al. 1988), observations that have since been confirmed with GnRH measurements (Horton et al. 1987, Goodman et al. 1995) and (3) the increase in LH pulse frequency induced by an EOP receptor antagonist in luteal phase ewes was associated with increased Fos expression in $\mathrm{MBH}$, but not POA, GnRH neurons (Boukhliqetal. 1999). The observation that microimplants in the $\mathrm{MBH}$ containing an antagonist selective for KOR, but not those containing an antagonist against the $\mu$ - or $\delta$-EOP receptors, increased $\mathrm{LH}$ pulse frequency in luteal phase ewes (Goodman et al. 2004) focused interest on dynorphin, the endogenous ligand for KOR. Subsequent work demonstrated that progesterone increased dynorphin concentrations in CSF collected from the third ventricle (Foradori et al. 2005), that almost all dynorphin neurons in the ARC and periventricular region of the POA contained the classical progesterone receptor (PR) (Foradori et al. 2002) that mediates the negative feedback actions of this steroid in ewes (Skinner et al. 1998) and that ARC PR-containing dynorphin neurons project to the region of the POA in which $\mathrm{GnRH}$ cell bodies are found (Dufourny et al. 2005). Because local administration of the PR antagonist, RU486, in the ARC increased LH pulse frequency in progesterone-treated OVX ewes, but RU486-containing microimplants had no effect when placed in the POA, it was concluded that ARC dynorphin (i.e., KNDy) neurons are the site of progesterone-negative feedback (Goodman et al. 2011). It should be noted, however, that local administration of progesterone to the ARC did not inhibit LH secretion in OVX, or OVX+E, ewes (Goodman et al. 2011). It is possible that progesterone from these microimplants did not affect a sufficient number of KNDy neurons to produce a measurable decrease in $\mathrm{LH}$ secretion or that the negative feedback actions of this steroid may involve other neurons/neurotransmitters in addition to KNDy neurons/dynorphin. One possible candidate is a population of neurons in the rostral ARC that contain both orphanin-FQ and PR since an antagonist to orphanin-FQ increased LH pulse frequency in luteal phase ewes (Nestor et al. 2013). Another possibility is the quarter of $\beta$-endorphin neurons in the ARC that contain PR and project to the POA (Dufourny et al. 2005). If these are involved, then they most likely act on POA GnRH neurons because a $\mu$-receptor antagonist (Goodman et al. 2004) or $\beta$-endorphin antisera (Weesner \& Malven 1990) acted in the POA, but not $\mathrm{MBH}$, to increase $\mathrm{LH}$ secretion in luteal phase ewes. This may be a redundant system since connections between the POA and $\mathrm{MBH}$ are not needed for progesterone-negative feedback (Whisnant \& Goodman 1994). However, this input may be important for the estrogen-induced $\mathrm{LH}$ surge in ewes (Walsh \& Clarke 1998).

Theoretically, progesterone suppression of kisspeptin or NKB release from KNDy neurons could also contribute to the inhibition of GnRH pulse frequency. The ability of KISS1R (Smith et al. 2011) and NK3R (Fraser et al. 2015, $\mathrm{Li}$ et al. 2015) antagonists to inhibit LH pulse frequency in OVX ewes is consistent with this possibility. However, there is no evidence that progesterone affects NKB expression, and little evidence that it affects kisspeptin expression, in ewes. There is one report that progesterone decreased Kiss 1 (determined using in situ hybridization $(\mathrm{ISH})$ ) in ewes that were OVX for 5-7 weeks (Smith et al. 2007), but this steroid does not inhibit LH secretion in chronically OVX ewes (Karsch et al. 1977). In contrast, no effect of progesterone was seen on Kiss 1 mRNA 
(measured using qPCR) when treatment began at the time of OVX; as expected, progesterone inhibited $\mathrm{LH}$ pulse frequency in these animals, but there was no correlation between LH pulse frequency and Kiss 1 levels (Weems et al. 2018). Thus, the negative feedback action of progesterone appears to be mediated by dynorphin release from KNDy neurons, although non-KNDy neurons may also contribute to this inhibition.

The role of different KNDy peptides in mediating the negative feedback actions of $E_{2}$ appears to be more complex than the relatively simple story for progesterone-negative feedback. Early studies, based on LH measurements, supported a role for EOP because the same EOP receptor antagonists that increased LH pulse frequency in the presence of progesterone increased $\mathrm{LH}$ pulse amplitude in follicular phase and estrogen-treated OVX ewes, but usually did not in untreated OVX ewes (Fig. 4) (Whisnant \& Goodman 1988, Yang et al. 1988, Goodman et al. 2002). However, direct measurements of $\mathrm{GnRH}$ did not support this hypothesis; the EOP receptor antagonist, naloxone, produced approximately a 3-fold increase in GnRH pulse amplitude in both OVX and OVX +E ewes (Fig. 4) (Goodman et al. 1995). Thus, the neurotransmitter-mediating estrogen-negative feedback in ewes remained unclear until the discovery of the reproductive actions of kisspeptin.

The hypothesis that $E_{2}$ inhibited $\mathrm{GnRH}$ pulse amplitude in ewes by inhibiting kisspeptin release from KNDy neurons was initially proposed based on studies in rodents (Dungan et al. 2006). However,
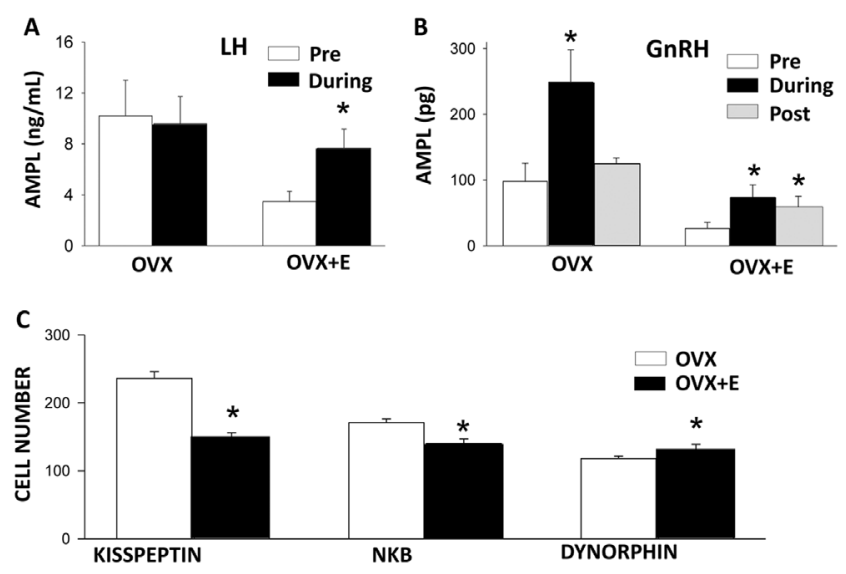

Figure 4 Evidence for possible roles of each KNDy peptide in mediating $E_{2}$ negative feedback in breeding season ewes. Top panels: Effect of an EOP receptor antagonist on mean ( \pm S.E.M.) LH (A) and GnRH (B) pulse amplitude in OVX and OVX $+E$ breeding season ewes. ${ }^{*} P<0.05$ vs pre-treatment values. Bottom panel (C): Effect of $\mathrm{E}_{2}$ on the mean ( \pm S.E.M.) number of cells in the ARC containing kisspeptin, NKB, or dynorphin in OVX breeding season ewes. $* P<0.05$ vs OVX. LH data reprinted from Whisnant and Goodman, Biol Reprod 39: 1032-38, 1988 with permission from the Society for the Study of Reproduction. GnRH and KNDy peptide data reprinted from Goodman et al. (1995) and Weems et al. (2017a), respectively, with permission of the Endocrine Society. strong evidence for this hypothesis was soon developed in ewes. First, virtually all KNDy neurons contain ER $\alpha$ (Franceschini et al. 2006). Second, OVX increased both the number of kisspeptin-ir neurons in the ARC (Smith et al. 2008) and the percentage of these neurons that contained Fos (Merkley et al. 2012). Third, estrogen treatment decreased Fos expression in ARC kisspeptin neurons (Smith et al. 2009), and consistently inhibited Kiss 1 expression (using ISH or qPCR) and kisspeptin-ir cell numbers in the ARC, but increased kisspeptin expression in the POA (Smith et al. 2007, 2008, Weems et al. 2017a). Finally, there was a positive correlation between Kiss 1 expression and LH pulse amplitude (but not frequency) in OVX ewes receiving either no treatment or steroid implants that produced luteal phase concentrations of progesterone and/or $E_{2}$ (Weems et al. 2018). While all these correlational studies support a role for ARC kisspeptin in $E_{2}$ negative feedback, there are only a few functional tests of this hypothesis in ewes. Varied results have been observed with i.c.v. administration of KISS1R antagonists to OVX ewes, with some researchers observing a decrease in $\mathrm{LH}$ pulse amplitude in response to p-234 (Roseweir et al. 2009), but others reporting inhibition of LH pulse frequency by the closely related p-271 (Smith et al. 2011). One possible explanation for this apparent discrepancy is that the former study used a lower dose $(40 \mu \mathrm{g} / \mathrm{h}$ of $\mathrm{p}$-234) than the latter $(300 \mu \mathrm{g} / \mathrm{h}$ of $\mathrm{p}$-271). Analysis of episodic LH patterns from one of our previous experiments (Goodman et al. 2012) confirmed that $40 \mu \mathrm{g} / \mathrm{h}$ of $\mathrm{p}-271$ inhibits LH pulse amplitude (from $9.2 \pm 1.4$ to $4.8 \pm 1.3 \mathrm{ng} / \mathrm{mL} ; \quad P<0.05, n=4)$ without affecting interpulse interval (before: $64.5 \pm 12.3 \mathrm{~min}$; during: $64.0 \pm 7.5 \mathrm{~min}$ ); a more dramatic effect on pulse amplitude was observed in two ewes that received $60 \mu \mathrm{g} / \mathrm{h}$ of this antagonist (a decrease from 13.9 \pm 1.6 to $2.9 \pm 0.1 \mathrm{ng} / \mathrm{mL}$ ), with again no change in interpulse interval. Thus, there are limited functional data and very strong correlational evidence supporting the hypothesis that a decrease in kisspeptin from KNDy neurons mediates $E_{2}$ inhibition of $\mathrm{GnRH}$ pulse amplitude in ewes, but additional functional studies are needed.

Whether changes in NKB and/or dynorphin contribute to the inhibition of $\mathrm{GnRH}$ pulse amplitude remains unclear. Changes in ARC NKB expression in response to changes in ovarian steroids parallel those of kisspeptin (Fig. 4): NKB increases with OVX and decreases with estrogen treatments (Weems et al. 2017a). Moreover, the ability of antagonists to NK3R to inhibit LH pulse amplitude in OVX ewes is consistent with this hypothesis (Fraser et al. 2015, Clarke et al. 2018). Decreases in LH pulse frequency were also seen in these studies, but a strong inhibition of $\mathrm{GnRH}$ pulse amplitude might lower LH pulse frequency if LH pulse amplitudes fall below the detection limit of the method used for pulse identification. Thus, an $E_{2}$ induced inhibition of NKB release could contribute to inhibition of GnRH pulse amplitude. There have been 
fewer studies on the possible role of dynorphin from KNDy neurons in estrogen-negative feedback because of earlier data indicating that $\mathrm{E}_{2}$ did not affect the naloxone-induced increase in $\mathrm{GnRH}$ pulse amplitude. However, the recent report that $E_{2}$ produced an increase in the number of dynorphin-ir cells in the ARC of OVX breeding season ewes (Fig. 4) has provided new support for this hypothesis (Weems et al. 2017a). In this regard, the earlier study examining GnRH pulse amplitude did observe that the naloxone-induced increase in pulse amplitude persisted after the end of naloxone infusion in OVX $+\mathrm{E}$, but not OVX, ewes (Fig. 4) (Goodman et al. 1995), suggesting a possible effect of $E_{2}$ on the dynamics of dynorphin release. Thus, further examination of the possible role of dynorphin in $E_{2}$-negative feedback in ewes is warranted.

Finally, it is interesting to note that the KNDy model for GnRH pulse generation provides a simple mechanism by which changes in NKB and/or dynorphin could contribute to the negative feedback action of $E_{2}$. There is evidence that dynorphin holds $\mathrm{GnRH}$ secretion in check during a pulse (Goodman et al. 1995, Weems et al. 2016a); if this action is mediated by a decrease in kisspeptin, one would predict that a slight increase in dynorphin would produce a decrease in kisspeptin release leading to lower GnRH pulse amplitude. Similarly, there is compelling evidence, including the cellular location of NK3R in ewes (Fig. 2), that NKB stimulates GnRH secretion via kisspeptin release from KNDy neurons (Weems et al. 2018). Thus, an $E_{2}$-induced decrease in NKB would be expected to act within the KNDy network to decrease kisspeptin release and subsequently GnRH pulse amplitude. In conclusion, it appears that KNDy neurons mediate the negative feedback actions of both progesterone and $E_{2}$ during the breeding season, with dynorphin and kisspeptin, respectively, being the primary outputs producing these effects.

\section{Effects of external inputs on GnRH pulsatility in adults}

Three external factors can clearly inhibit pulsatile GnRH secretion in adult ewes: stressors, undernutrition and photoperiod. While it is well known that stress can inhibit GnRH secretion in a number of species including sheep, the underlying neuroendocrine mechanisms are complex and not completely understood. The effects of a variety of different stressors on pulsatile $\mathrm{LH}$ secretion have been examined in ewes, ranging in severity (based on cortisol concentrations produced by each stressor) from mild (psychosocial and transport stress) through moderate (insulin-induced hypoglycemia) to severe (endotoxin). Although there is little direct information on pulsatile GnRH secretion, all four stressors likely inhibit GnRH pulse frequency based on their ability to inhibit LH pulse frequency (Goodman \& Inskeep 2006).
However, measurements of GnRH pulses demonstrated that endotoxin (Battaglia et al. 1997) and psychosocial stress (Wagenmaker et al. 2009) inhibit GnRH pulse amplitude, but had less consistent effects on GnRH pulse frequency; psychosocial stress had no consistent effect on pulse frequency, while endotoxin inhibited pulsatile $\mathrm{GnRH}$ secretion, but did not significantly decrease pulse frequency because of variability in the timing of this inhibition. It should be noted that these experiments were done using OVX ewes so the results do not rule out a stronger inhibition of $\mathrm{GnRH}$ pulsatility in ovary-intact animals (see below).

There has been considerable work on the role of increased cortisol concentrations in the stress-induced inhibition of episodic $\mathrm{GnRH} / \mathrm{LH}$ secretion that has revealed a major difference in the actions of this glucocorticoid depending on the presence or absence of ovarian steroids (Ralph et al. 2016). In OVX ewes, cortisol acts solely at the pituitary via the type II glucocorticoid receptor (GR) to inhibit the response to $\mathrm{GnRH}$, and thus, blunts $\mathrm{LH}$ pulse amplitude, without altering $\mathrm{LH}$ pulse frequency or episodic GnRH secretion (Breen \& Karsch 2004). In contrast, in follicular phase animals or in OVX ewes given exogenous steroids to mimic a follicular phase, cortisol inhibits GnRH (Oakley et al. 2009a) and LH (Breen et al. 2005, Oakley et al. 2009a,b) pulse frequency. Cortisol produced no consistent effects on GnRH pulse amplitude (Oakley et al. 2009a) with a modest inhibition of $\mathrm{LH}$ pulse amplitude seen in some, but not all, studies (Breen et al. 2005, Oakley et al. $2009 a, b)$. There is one report that the inhibition of $\mathrm{GnRH}$ pulse amplitude by psychosocial stress was not affected by the GR (and PR) antagonist, RU486 (Wagenmaker et al. 2009), but this experiment used OVX ewes, so its relevance to normal animals remains unclear. Thus, in ovary-intact ewes, cortisol produces a significant decrease in $\mathrm{GnRH}$ pulse frequency that likely contributes to the inhibitory effects of stress.

There is essentially no published data on the role of KNDy neurons in the inhibitory response to cortisol in ewes, but we have preliminary evidence that dynorphin release from KNDy neurons in the middle ARC may play a role. This subpopulation of KNDy neurons, but not KNDy neurons in the caudal or rostral ARC, contains GR and exogenous cortisol increases pre-prodynorphin mRNA and dynorphin protein expression in this KNDy subpopulation (Ralph et al. 2016). If these data are confirmed they will provide another important function for KNDy neurons in the control of episodic GnRH secretion. Finally, it is important to note that cortisol, by itself, cannot account for the inhibition of episodic $\mathrm{GnRH}$ or LH secretion by stressors (Debus et al. 2002, Wagenmaker et al. 2009), so neural systems activated (or inhibited) by these stressors must play some role. However, the systems involved remain largely unknown because the most likely candidates (corticotropin releasing hormone or arginine vasopressin) do not inhibit, 
and in some cases actually stimulate, $\mathrm{LH}$ secretion in ewes (Goodman \& Inskeep 2006). Recent work has focused on a possible role for RFRP-3 neurons because stronger stressors, such as insulin or endotoxin, increase Fos expression in RFRP-3 neurons and the percentage of $\mathrm{GnRH}$ cells with close contacts containing RFRP-3 (Papargiris et al. 2011, Clarke et al. 2016). However, the functional significance of these changes awaits studies determining if antagonists to the RFRP-3 receptor can block the stress-induced inhibition of $\mathrm{GnRH}$ or $\mathrm{LH}$.

As is the case for pre-pubertal ewe lambs, undernutrition in adult ewes reduces LH secretion. However, in the adult ewe, a longer duration of food restriction is required to produce a reduction in $\mathrm{LH}$ (e.g. pre-pubertal: 2 months (Wang et al. 2016); adult: 6 months (Backholer et al. 2010a)), which is thought to reflect the larger metabolic reserve (i.e., adipose) in the adult. One possible peripheral signal linking nutrition to reproduction is the adipose-derived hormone leptin. Circulating concentrations of leptin closely correlate with body fat (Delavaud et al. 2000, Daniel et al. 2002), are reduced during times of undernutrition (Daniel et al. 2002) and are associated with fertility and ovulation rate in sheep (Nieto et al. 2013). While there is little evidence for a central action of leptin on LH secretion in pre-pubertal ewes, central administration of leptin in chronically food-restricted adult ewes stimulates LH secretion (Henry et al. 2001, Backholer et al. 2010a). Given that $\mathrm{GnRH}$ neurons in other species appear to be devoid of leptin receptors (Finn et al. 1998, Hakansson et al. 1998), the stimulatory action of centrally administered leptin is likely upstream of these key reproductive neurons.

In sheep, there are currently limited data as to whether KNDy neurons are part of the central mechanisms whereby undernutrition inhibits $\mathrm{GnRH} / \mathrm{LH}$ release. It has been shown that chronic food restriction (6-10 months) reduced kisspeptin mRNA expression in the POA and ARC of OVX ewes, an effect that was partially restored with a sustained central infusion of leptin (Backholer et al. 2010b). Initially, KNDy neurons were thought to be direct targets of leptin because essentially all ARC kisspeptin neurons express leptin receptors (Backholer et al. 2010b). However, this concept has since been challenged by others who demonstrated that leptin administration fails to activate ARC kisspeptin neurons as assessed with p-STAT3-ir (Louis et al. 2011). Interestingly, KNDy neurons may serve as an intermediary for classic energy sensing neurons such as proopiomelanocortin (POMC) and NPY/agouti-related peptide (AgRP) neurons, both of which are known to influence reproduction in several species. In adult ewes, ARC kisspeptin neurons receive afferent input from both POMC and NPY neurons (Backholer et al. 2010b), but the effect of energy balance on this connection remains to be determined. Furthermore, central infusion of melanotan II, an agonist for $\alpha-\mathrm{MSH}$ receptors, stimulated LH secretion in fed (Backholer et al. 2009) and food-restricted adult ewes (Backholer et al. 2010a), but the specific role of KNDy neurons in the actions of POMC and/or NPY/AgRP neurons to control $\mathrm{GnRH} / \mathrm{LH}$ secretion remains largely unknown.

In contrast to stress and nutrition, the effects of photoperiod on reproduction have been extensively investigated, and there is thus considerable information on the neural systems involved in the photoperiodic control of GnRH pulses in ewes. In most breeds of sheep, ewes have annual fluctuations in fertility, with ovulatory cycles occurring in the fall and winter months (breeding season) and no ovulations during the spring and summer months (anoestrous season). The timing of these fluctuations is controlled by the external photoperiod (hours of light/day) and ensures that lambs are born in the spring when environmental conditions favor their survival (Hazlerigg \& Simonneaux 2015). Studies of seasonal breeding fall into two major categories: (1) the mechanisms by which changes in photoperiod are perceived and (2) seasonal changes in the hypothalamohypophyseal unit that produce fertility and infertility. The former, which involves photoperiod-induced changes in melatonin secretion from the pineal gland and its actions in the pars tuberalis is beyond the scope of this review; for interested readers, details can be found in several recent reviews (Goodman et al. 2010, Hazlerigg \& Simonneaux 2015, Weems et al. 2015). Instead, we will focus on the latter, which involves changes in pulsatile GnRH secretion.

Early studies on the neuroendocrine mechanisms responsible for the seasonal changes in fertility in ewes found that (1) there is a marked increase in response to the negative feedback actions of $E_{2}$ in the anoestrous season (Legan et al. 1977), (2) this increase reflects a change in the effects of $E_{2}$ on episodic $\mathrm{GnRH}$ secretion; during the breeding season, $\mathrm{E}_{2}$ inhibits $\mathrm{GnRH}$ pulse amplitude while during anoestrus it strongly inhibits GnRH pulse frequency (Goodman et al. 1982) and (3) there is a modest decrease in $\mathrm{GnRH}$ pulse frequency in anoestrous OVX ewes (known as the steroid-independent effects of photoperiod), which is accompanied by an increase in pulse amplitude (Goodman et al. 1982).

Much of the work on seasonal breeding after these initial observations, and before the discovery of kisspeptin, focused on the neural mechanisms underlying the shifts in the ability of $E_{2}$ to inhibit $\mathrm{GnRH}$ pulse frequency (Goodman et al. 2010). Briefly, the model that developed from this work proposed that a group of inhibitory dopaminergic (DA) neurons in the retrochiasmatic area of the ovine hypothalamus, known as A15 neurons (Thiery et al. 1989, 1995), are only active in anoestrus and mediate the negative feedback actions of $E_{2}$ on $\mathrm{GnRH}$ pulse frequency at this time of year (Havern et al. 1994, Lehman et al. 1996). A15 neurons do not contain $E R \alpha$ and are thought to receive estrogen-responsive afferents (possibly GABAergic or 
glutamatergic neurons (Bogusz et al. 2008, Singh et al. 2009)) from the POA (Anderson et al. 2001) and retrochiasmatic area (Gallegos-Sanchez et al. 1997, Hardy et al. 2003) that stimulate these inhibitory neurons. This population of DA neurons project caudally to the $\mathrm{MBH}$, not rostrally to the POA (Gayrard et al. 1995, Goodman et al. 2010), but the mechanisms by which A15 neurons inhibit $\mathrm{GnRH} / \mathrm{LH}$ pulse frequency during anoestrus remained largely unknown until recently, when a model incorporating KNDy neurons was developed.

This model arose from the initial observation that there is a seasonal difference in the ability of $E_{2}$ to inhibit kisspeptin expression in the ARC (Smith et al. 2008). During the breeding season, $E_{2}$ decreases the number of kisspeptin-containing KNDy neurons, but this effect is greatly enhanced in anoestrus. Thus, there are many fewer kisspeptin neurons in the ARC (but not in the $P O A)$, of $E_{2}$-treated OVX ewes during anoestrus than during the breeding season. This seasonal difference is associated with a decrease in kisspeptin inputs to $\mathrm{MBH}$, but not POA, GnRH neurons (Smith et al. 2008).

These data led to the hypothesis that A15 DA neurons act via inhibition of kisspeptin release to reduce $\mathrm{GnRH} /$ LH pulse frequency in anestrous ewes, which is now supported by several lines of evidence. First, most KNDy neurons contain the D2 dopamine receptor (Goodman et al. 2012, Weems et al. 2017a) that mediates the actions of DA on GnRH pulse frequency in anoestrus (Goodman et al. 2010). Second, $E_{2}$ increases both the percentage of KNDy neurons containing the D2 receptor and those receiving DA-containing close contacts in anoestrous ewes (Weems et al. 2017a). Finally, functional evidence for this connection includes the ability of microinjections of the $\mathrm{D} 2$ receptor antagonist, pimozide, into the $\mathrm{ARC}$ to increase $\mathrm{LH}$ pulse frequency in anoestrus and that the stimulatory actions of an i.m. injection of pimozide were blocked by i.c.v. infusions of the KISS1R antagonist, p-271 (Goodman et al. 2012). Based on these data, it has been proposed that the increased ability of $E_{2}$ to inhibit GnRH pulse frequency in anoestrus reflects both increased release of DA from A15 projections onto KNDy neurons and an increased response of KNDy neurons to this inhibitory neurotransmitter.

Recent work has raised the possibility that two other neurotransmitters, RFamide-related peptide-3 (RFRP-3) and somatostatin, may also be involved in the seasonal regulation of episodic GnRH secretion. The number of RFRP-3-ir cell bodies in the paraventricular nucleus (PVN) and dorsomedial hypothalamus (DMH) increases during anoestrus in estrogen-treated OVX ewes (Smith et al. 2008), and RFRP-3 concentrations in hypophyseal portal blood of ovary-intact ewes are higher in anoestrus than in the breeding season (Smith et al. 2012). The ISH data on expression of mRNA for RFRP-3 are inconsistent, with one report of a small (17\%) increase in the PVN/ $\mathrm{DMH}$ in ewes transferred from short to long days
(Dardente et al. 2008) but another that found no effect of season in ewes kept on natural photoperiod (Smith et al. 2008). Studies on the possible actions of RFRP-3 in ewes have focused mainly on potential effects at the pituitary and there is both in vitro (Clarke et al. 2008, Sari et al. 2009) and in vivo (Clarke et al. 2012, Smith et al. 2012) evidence that RFRP-3 decreases GnRH-induced LH secretion. However, the in vivo studies used doses of RFRP-3 that produced concentrations of this peptide in the hypophyseal portal circulation many times greater than those in normal animals (Smith et al. 2012), and these results were not confirmed by another group (Caraty et al. 2012, Decourt et al. 2016). There may be important seasonal effects of RFRP-3 on GnRH secretion because RFRP-3 input to $\mathrm{GnRH}$ neurons increases in anestrus (Smith et al. 2008). However, expression of the RFRP-3 receptor was not found in areas containing $\mathrm{GnRH}$ cell bodies (Dardente et al. 2008) and administration of either RFRP-3 (Caraty et al. 2012) or a specific antagonist to the RFRP-3 receptor (Decourt et al. 2016) into the third ventricle had no effect on LH secretion. Thus, any conclusions on the role of RFRP-3 in seasonal changes in pulsatile secretion of $\mathrm{GnRH} / \mathrm{LH}$ in ewes await further work to resolve the contradictory data currently available.

There is stronger evidence that somatostatin contributes to the steroid-independent actions of inhibitory photoperiod. Specifically, i.c.v. injections of a somatostatin receptor antagonist increased LH pulse frequency in OVX anestrous ewes to levels similar to those in OVX breeding season animals, but this antagonist had no effects in the latter (McCosh et al. 2017). A seasonal difference was also observed in ovary-intact animals with a $300 \%$ increase in mean LH concentrations in anoestrous animals compared to only a $40 \%$ increase in breeding season (luteal phase) ewes (McCosh et al. 2017). Interestingly, this somatostatin receptor antagonist also produced a modest increase in the percentage of kisspeptin neurons containing Fos in the caudal ARC in ovary-intact anestrous ewes. This limited activation of KNDy neurons could reflect the relatively modest changes in $\mathrm{LH}$ pulse frequency produced by the steroidindependent effects of photoperiod. Because early pharmacological data had implicated serotonin in the seasonal changes in LH pulse frequency in OVX ewes, it was proposed that serotonin acts via somatostatin interneurons to inhibit KNDy neurons.

\section{Conclusion}

Classic studies in the 1980s and 1990s provide a wealth of evidence on the control of pulsatile GnRH secretion by internal (i.e., ovarian steroids) and external (i.e. stress, nutrition, and photoperiod) inputs in ewes. However, all these findings had to be interpreted in the context of the 'GnRH pulse generator' being considered a 'black box' because of the paucity of information on the neural 
mechanisms driving episodic GnRH secretion. The recent discovery of the reproductive actions of kisspeptin, and the subsequent development of the KNDy hypothesis for $\mathrm{GnRH}$ pulse generation, provide a basis for novel neural mechanisms by which these inputs control $\mathrm{GnRH}$, and thus $\mathrm{LH}$, pulses.

While the roles of ovine KNDy neurons in mediating the actions of these internal and external inputs have yet to be extensively studied, some useful conclusions can be drawn (Fig. 5). The strongest of these are the mechanisms by which ovarian steroids inhibit LH secretion in adult ewes. During the breeding season,

\section{Ewe Lambs}

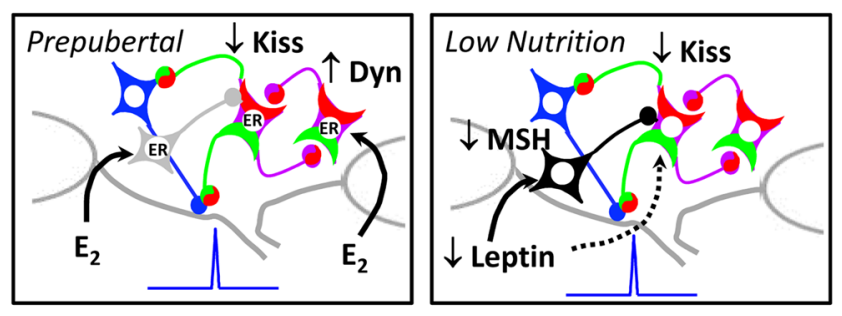

Adult Ewes
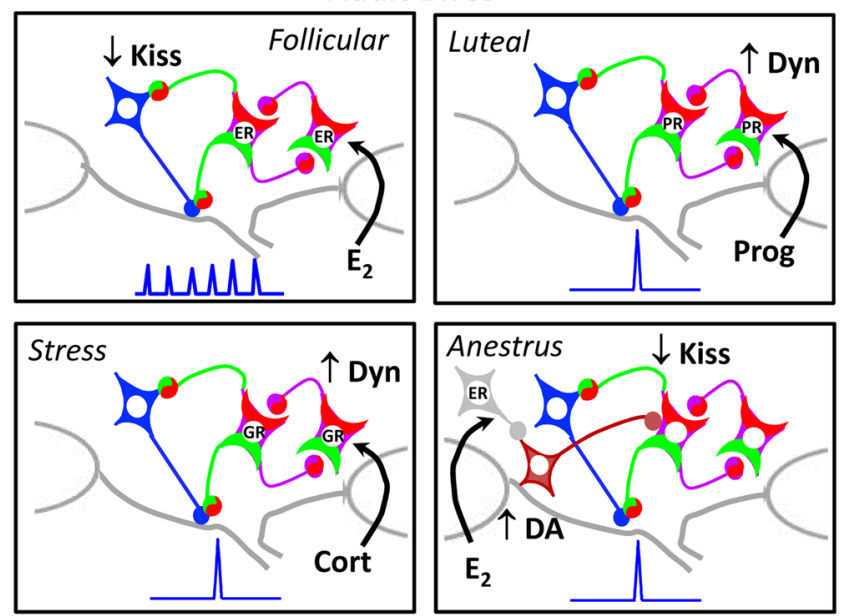

Figure 5 Role of KNDy neurons in the control of pulsatile GnRH secretion in ewes under different physiological conditions. In well-fed prepubertal lambs (top left panel), GnRH pulse frequency is held in check by $\mathrm{E}_{2}$-induced decreases in kisspeptin and increases in dynorphin release, but this could be due to either direct or indirect actions of $E_{2}$ on KNDy neurons. In lambs (and adult ewes) on a low level of nutrition (top right panel), a fall in leptin suppresses $\mathrm{GnRH}$ release by inhibiting kisspeptin via $\mathrm{MSH}$; it is unclear if leptin also has direct effects on KNDy neurons. In breeding season adults (middle panels), $E_{2}$ acts during the follicular phase to decrease kisspeptin release and thus GnRH pulse amplitude and progesterone acts during the luteal phase to inhibit pulse frequency via an increase in dynorphin. In follicular phase ewes, stressors inhibit GnRH pulse frequency via cortisol, which may act to increase dynorphin output from KNDy neurons (bottom left panel) and unidentified neural inputs (not illustrated). In anoestrous ewes (bottom right panel), $E_{2}$ acts via afferent input to increase DA release from A15 neurons that innervate KNDy neurons and inhibit kisspeptin and thus $\mathrm{GnRH}$ pulse frequency. there is strong evidence that progesterone inhibits $\mathrm{GnRH}$ pulse frequency via increased dynorphin release from KNDy neurons which likely acts within the KNDy network and directly on $\mathrm{GnRH}$ neurons. In contrast, during this season $\mathrm{E}_{2}$ inhibits $\mathrm{GnRH}$ pulse amplitude by inhibiting kisspeptin release onto $\mathrm{GnRH}$ neurons, although a role for changes in NKB and/or dynorphin release onto other KNDy neurons cannot be ruled out. In adult anoestrous ewes, the inhibitory photoperiod activates A15 DA neurons, which respond to an increase in $E_{2}$ by releasing DA onto KNDy neurons to inhibit $\mathrm{GnRH}$ pulse frequency.

There is relatively less information on the role of KNDy neurons in controlling episodic GnRH secretion prior to puberty and in response to stressors and undernutrition. Prior to puberty it is clear that $E_{2}$ inhibits $\mathrm{GnRH}$ pulse frequency. There is strong evidence that this reflects an inhibition of kisspeptin release from KNDy neurons, and stimulation of dynorphin release (which may come from KNDy neurons), that wanes with the decrease in the negative feedback actions of $E_{2}$ during puberty (Fig. 5). There is some evidence that an increase in NKB may also be involved in puberty in ewe lambs, but this hypothesis requires further testing. Moreover, whether $E_{2}$ acts directly on KNDy neurons prior to puberty to inhibit $\mathrm{GnRH}$ pulse frequency or via neurons afferent to the KNDy network, as it does during anoestrus, remains to be determined. Even less is known about the role of KNDy neurons in the response to undernutrition and stress in ewes. Inadequate nutrition undoubtedly inhibits leptin concentrations which likely decrease KNDy neural activity possibly via POMC or AgRP neurons in both lambs and adult ewes. However, much of the data for this hypothesis relies on work in other species (Manfredi-Lozano et al. 2016, Padilla et al. 2017). Similarly, stressors clearly inhibit $\mathrm{GnRH}$ pulse frequency in ewes; this likely reflects both direct effects of cortisol on KNDy neural activity and the activation of unknown afferents that also inhibit the activity of the GnRH pulse generator. Finally, it is important to note that earlier work implicated many other neurotransmitters (e.g., glutamate, GABA, norepinephrine) in the control of episodic $\mathrm{GnRH}$ secretion in ewes (Goodman \& Inskeep 2015); the possible interaction of some of these (e.g., glutamate (Goodman et al. 2013, Ezzat et al. 2015, Merkley et al. 2015)) with KNDy neurons has started to be explored, but more work is needed to integrate earlier and more recent data sets. In conclusion, the development of the KNDy hypothesis for $\mathrm{GnRH}$ pulse generation has also set the stage for a more detailed understanding of the neural systems by which external and internal inputs modify pulsatile GnRH secretion in ewes. Although these investigations are in their early stages, this model can be used to develop specific hypotheses and predictions that can then be tested in future work. 


\section{Declaration of interest}

The authors declare that there is no conflict of interest that could be perceived as prejudicing the impartiality of this review.

\section{Funding}

Work presented in this review received support from the National Institutes of Health Grants R01-HD039916, R01-HD017864, R01-HD082135 to R L G and M N L and from the National Institute of Food and Agriculture, U.S. Department of Agriculture, award number 2013-67015-20956 to $\mathrm{S} M \mathrm{H}$.

\section{Acknowledgments}

The authors thank many students, post-doctoral fellows and colleagues who made critical contributions to our work described in this review.

\section{References}

Amstalden M, Coolen LM, Hemmerle AM, Billings HJ, Connors JM, Goodman RL \& Lehman MN 2010 Neurokinin 3 receptor immunoreactivity in the septal region, preoptic area and hypothalamus of the female sheep: colocalisation in neurokinin B cells of the arcuate nucleus but not in gonadotrophin-releasing hormone neurones. Journal of Neuroendocrinology 22 1-12. (https://doi.org/10.1111/j.13652826.2009.01930.x)

Anderson GM, Connors JM, Hardy SL, Valent M \& Goodman RL 2001 Oestradiol microimplants in the ventromedial preoptic area inhibit secretion of luteinizing hormone via dopamine neurones in anoestrous ewes. Journal of Neuroendocrinology 13 1051-1058. (https://doi. org/10.1046/j.1365-2826.2001.00726.x)

Backholer K, Smith J \& Clarke IJ 2009 Melanocortins may stimulate reproduction by activating orexin neurons in the dorsomedial hypothalamus and kisspeptin neurons in the preoptic area of the ewe. Endocrinology 150 5488-5497. (https://doi.org/10.1210/en.2009-0604)

Backholer K, Bowden M, Gamber K, Bjorbaek C, Iqbal J \& Clarke IJ 2010a Melanocortins mimic the effects of leptin to restore reproductive function in lean hypogonadotropic ewes. Neuroendocrinology 91 27-40. (https:// doi.org/10.1159/000260060)

Backholer K, Smith JT, Rao A, Pereira A, Iqbal J, Ogawa S, Li Q \& Clarke IJ $2010 b$ Kisspeptin cells in the ewe brain respond to leptin and communicate with neuropeptide $Y$ and proopiomelanocortin cells. Endocrinology 151 2233-2243. (https://doi.org/10.1210/en.2009-1190)

Barker-Gibb ML, Scott CJ, Boublik JH \& Clarke IJ 1995 The role of neuropeptide $\mathrm{Y}$ (NPY) in the control of LH secretion in the ewe with respect to season, NPY receptor subtype and the site of action in the hypothalamus. Journal of Endocrinology 147 565-579. (https://doi. org/10.1677/joe.0.1470565)

Battaglia DF, Bowen JM, Krasa HB, Thrun LA, Viguie C \& Karsch FJ 1997 Endotoxin inhibits the reproductive neuroendocrine axis while stimulating adrenal steroids: a simultaneous view from hypophyseal portal and peripheral blood. Endocrinology 138 4273-4281. (https://doi. org/10.1210/endo.138.10.5449)

Belchetz PE, Plant TM, Nakai Y, Keogh EJ \& Knobil E 1978 Hypophysial responses to continuous and intermittent delivery of hypopthalamic gonadotropin-releasing hormone. Science 202 631-633. (https://doi. org/10.1126/science.100883)

Blum JJ, Reed MC, Janovick JA \& Conn PM 2000 A mathematical model quantifying GnRH-induced LH secretion from gonadotropes. American Journal of Physiology: Endocrinology and Metabolism 278 E263-E272. (https://doi.org/10.1152/ajpendo.2000.278.2.E263)
Bogusz AL, Hardy SL, Lehman MN, Connors JM, Hileman SM, Sliwowska JH, Billings HJ, McManus CJ, Valent M, Singh SR et al. 2008 Evidence that gamma-aminobutyric acid is part of the neural circuit mediating estradiol negative feedback in anestrous ewes. Endocrinology 149 2762-2772. (https://doi.org/10.1210/en.2007-1362)

Boukhliq R, Goodman RL, Berriman SJ, Adrian B \& Lehman MN 1999 A subset of gonadotropin-releasing hormone neurons in the ovine medial basal hypothalamus is activated during increased pulsatile luteinizing hormone secretion. Endocrinology 140 5929-5936. (https://doi. org/10.1210/endo.140.12.7216)

Breen KM \& Karsch FJ 2004 Does cortisol inhibit pulsatile luteinizing hormone secretion at the hypothalamic or pituitary level? Endocrinology 145 692-698. (https://doi.org/10.1210/en.2003-1114)

Breen KM, Billings HJ, Wagenmaker ER, Wessinger EW \& Karsch FJ 2005 Endocrine basis for disruptive effects of cortisol on preovulatory events. Endocrinology 146 2107-2115. (https://doi.org/10.1210/en.2004-1457)

Caraty A \& Locatelli A 1988 Effect of time after castration on secretion of LHRH and LH in the ram. Journal of Reproduction and Fertility $\mathbf{8 2}$ 263-269. (https://doi.org/10.1530/jrf.0.0820263)

Caraty A, Smith JT, Lomet D, Ben Said S, Morrissey A, Cognie J, Doughton B, Baril G, Briant C \& Clarke IJ 2007 Kisspeptin synchronizes preovulatory surges in cyclical ewes and causes ovulation in seasonally acyclic ewes. Endocrinology 148 5258-5267. (https://doi.org/10.1210/ en.2007-0554)

Caraty A, Blomenrohr M, Vogel GM, Lomet D, Briant C \& Beltramo M 2012 RF9 powerfully stimulates gonadotrophin secretion in the ewe: evidence for a seasonal threshold of sensitivity. Journal of Neuroendocrinology 24 725-736. (https://doi.org/10.1111/j.1365-2826.2012.02283.x)

Caraty A, Lomet D, Sebert ME, Guillaume D, Beltramo M \& Evans NP 2013 Gonadotrophin-releasing hormone release into the hypophyseal portal blood of the ewe mirrors both pulsatile and continuous intravenous infusion of kisspeptin: an insight into kisspeptin's mechanism of action. Journal of Neuroendocrinology 25 537-546. (https://doi.org/10.1111/ jne.12030)

Chakraborty PK, Adams TE, Tarnavsky GK \& Reeves JJ 1974 Serum and pituitary $\mathrm{LH}$ concentrations in ewes infused with $\mathrm{LH}-\mathrm{RH} / \mathrm{FSH}-\mathrm{RH}$. Journal of Animal Science 39 1150-1157. (https://doi.org/10.2527/ jas1974.3961150x)

Clarke IJ 1993 Variable patterns of gonadotropin-releasing hormone secretion during the estrogen-induced luteinizing hormone surge in ovariectomized ewes. Endocrinology 133 1624-1632. (https://doi. org/10.1210/endo.133.4.8404603)

Clarke IJ 1995 The preovulatory LH surge A case of a neuroendocrine switch. Trends in Endocrinology and Metabolism 6 241-247. (https:// doi.org/10.1016/1043-2760(95)95218-T)

Clarke IJ \& Cummins JT 1982 The temporal relationship between gonadotropin releasing hormone $(\mathrm{GnRH})$ and luteinizing hormone (LH) secretion in ovariectomized ewes. Endocrinology 111 1737-1739. (https://doi.org/10.1210/endo-111-5-1737)

Clarke IJ, Thomas GB, Yao B \& Cummins JT 1987 GnRH secretion throughout the ovine estrous cycle. Neuroendocrinology 46 82-88. (https://doi.org/10.1159/000124800)

Clarke IJ, Sari IP, Qi Y, Smith JT, Parkington HC, Ubuka T, Iqbal J, Li Q, Tilbrook A, Morgan K et al. 2008 Potent action of RFamide-related peptide-3 on pituitary gonadotropes indicative of a hypophysiotropic role in the negative regulation of gonadotropin secretion. Endocrinology 149 5811-5821. (https://doi.org/10.1210/en.2008-0575)

Clarke IJ, Smith JT, Henry BA, Oldfield BJ, Stefanidis A, Millar RP, Sari IP, Chng K, Fabre-Nys C, Caraty A et al. 2012 Gonadotropin-inhibitory hormone is a hypothalamic peptide that provides a molecular switch between reproduction and feeding. Neuroendocrinology 95 305-316. (https://doi.org/10.1159/000332822)

Clarke IJ, Bartolini D, Conductier G \& Henry BA 2016 Stress increases gonadotropin inhibitory hormone cell activity and input to $\mathrm{GnRH}$ cells in ewes. Endocrinology 157 4339-4350. (https://doi.org/10.1210/ en.2016-1513)

Clarke IJ, Li Q, Henry BA \& Millar RP 2018 Continuous kisspeptin restores luteinizing hormone pulsatility following cessation by a neurokinin B antagonist in female sheep. Endocrinology 159 639-646. (https://doi. org/10.1210/en.2017-00737)

Clarkson J, Han SY, Piet R, McLennan T, Kane GM, Ng J, Porteous RW, Kim JS, Colledge WH, Iremonger KJ et al. 2017 Definition of the 
hypothalamic GnRH pulse generator in mice. PNAS 114 E10216E10223. (https://doi.org/10.1073/pnas.1713897114)

d'Anglemont de Tassigny X, Fagg LA, Dixon JP, Day K, Leitch HG, Hendrick AG, Zahn D, Franceschini I, Caraty A, Carlton MB et al. 2007 Hypogonadotropic hypogonadism in mice lacking a functional Kiss1 gene. PNAS 104 10714-10719. (https://doi.org/10.1073/ pnas.0704114104)

Daniel JA, Whitlock BK, Baker JA, Steele B, Morrison CD, Keisler DH \& Sartin JL 2002 Effect of body fat mass and nutritional status on 24-hour leptin profiles in ewes. Journal of Animal Science 80 1083-1089. (https:// doi.org/10.2527/2002.8041083x)

Dardente H, Birnie M, Lincoln GA \& Hazlerigg DG 2008 RFamide-related peptide and its cognate receptor in the sheep: cDNA cloning, mRNA distribution in the hypothalamus and the effect of photoperiod. Journal of Neuroendocrinology 20 1252-1259. (https://doi.org/10.1111/j.13652826.2008.01784.x)

de Roux N, Genin E, Carel JC, Matsuda F, Chaussain JL \& Milgrom E 2003 Hypogonadotropic hypogonadism due to loss of function of the KiSS1derived peptide receptor GPR54. PNAS 100 10972-10976. (https://doi. org/10.1073/pnas.1834399100)

Debus N, Breen KM, Barrell GK, Billings HJ, Brown M, Young EA \& Karsch FJ 2002 Does cortisol mediate endotoxin-induced inhibition of pulsatile luteinizing hormone and gonadotropin-releasing hormone secretion? Endocrinology 143 3748-3758. (https://doi.org/10.1210/ en.2002-220291)

Decourt C, Anger K, Robert V, Lomet D, Bartzen-Sprauer J, Caraty A, Dufourny L, Anderson G \& Beltramo M 2016 No evidence that RFamide-related peptide 3 directly modulates LH secretion in the ewe. Endocrinology 157 1566-1575. (https://doi.org/10.1210/en.2015-1854)

Delavaud C, Bocquier F, Chilliard Y, Keisler DH, Gertler A \& Kann G 2000 Plasma leptin determination in ruminants: effect of nutritional status and body fatness on plasma leptin concentration assessed by a specific RIA in sheep. Journal of Endocrinology 165 519-526. (https://doi.org/10.1677/ joe.0.1650519)

Dierschke DJ, Bhattacharya AN, Atkinson LE \& Knobil E 1970 Circhoral oscillations of plasma LH levels in the ovariectomized rhesus monkey. Endocrinology 87 850-853. (https://doi.org/10.1210/endo-87-5-850)

Dufourny L, Caraty A, Clarke IJ, Robinson JE \& Skinner DC 2005 Progesterone-receptive beta-endorphin and dynorphin B neurons in the arcuate nucleus project to regions of high gonadotropin-releasing hormone neuron density in the ovine preoptic area. Neuroendocrinology 81 139-149. (https://doi.org/10.1159/000086527)

Dungan HM, Clifton DK \& Steiner RA 2006 Minireview: kisspeptin neurons as central processors in the regulation of gonadotropinreleasing hormone secretion. Endocrinology 147 1154-1158. (https:// doi.org/10.1210/en.2005-1282)

Ebling FJ, Wood RI, Karsch FJ, Vannerson LA, Suttie JM, Bucholtz DC, Schall RE \& Foster DL 1990 Metabolic interfaces between growth and reproduction. III. Central mechanisms controlling pulsatile luteinizing hormone secretion in the nutritionally growth-limited female lamb. Endocrinology 126 2719-2727. (https://doi.org/10.1210/endo-126-52719)

Evans NP, Dahl GE, Mauger D \& Karsch FJ 1995a Estradiol induces both qualitative and quantitative changes in the pattern of gonadotropinreleasing hormone secretion during the presurge period in the ewe. Endocrinology 136 1603-1609. (https://doi.org/10.1210/ endo.136.4.7895670)

Evans NP, Dahl GE, Mauger DT, Padmanabhan V, Thrun LA \& Karsch FJ $1995 b$ Does estradiol induce the preovulatory gonadotropin-releasing hormone $(\mathrm{GnRH})$ surge in the ewe by inducing a progressive change in the mode of operation of the GnRH neurosecretory system. Endocrinology 136 5511-5519. (https://doi.org/10.1210/endo.136.12.7588302)

Ezzat A, Pereira A \& Clarke IJ 2015 Kisspeptin is a component of the pulse generator for $\mathrm{GnRH}$ secretion in female sheep but not the pulse generator. Endocrinology 156 1828-1837. (https://doi.org/10.1210/ en.2014-1756)

Finn PD, Cunningham MJ, Pau KY, Spies HG, Clifton DK \& Steiner RA 1998 The stimulatory effect of leptin on the neuroendocrine reproductive axis of the monkey. Endocrinology 139 4652-4662. (https://doi.org/10.1210/ endo.139.11.6297)

Fitzgerald J, Michel F \& Butler WR 1982 Growth and sexual maturation in ewes: dietary and seasonal effects modulating luteinizing hormone secretion and first ovulation. Biology of Reproduction 27 864-870. (https://doi.org/10.1095/biolreprod27.4.864)

Foradori CD, Coolen LM, Fitzgerald ME, Skinner DC, Goodman RL \& Lehman MN 2002 Colocalization of progesterone receptors in parvicellular dynorphin neurons of the ovine preoptic area and hypothalamus. Endocrinology 143 4366-4374. (https://doi.org/10.1210/ en.2002-220586)

Foradori CD, Goodman RL, Adams VL, Valent M \& Lehman MN 2005 Progesterone increases dynorphin a concentrations in cerebrospinal fluid and preprodynorphin messenger ribonucleic acid levels in a subset of dynorphin neurons in the sheep. Endocrinology 146 1835-1842. (https://doi.org/10.1210/en.2004-1326)

Foradori CD, Amstalden M, Goodman RL \& Lehman MN 2006 Colocalisation of dynorphin a and neurokinin B immunoreactivity in the arcuate nucleus and median eminence of the sheep. Journal of Neuroendocrinology 18 534-541. (https://doi.org/10.1111/j.13652826.2006.01445.x)

Foster DL \& Hileman SM 2015 Puberty in the sheep. In Knobil and Neill's Physiology of Reproduction, 4th ed., Elsevier, Amsterdam pp 1441-1485.

Foster DL \& Olster DH 1985 Effect of restricted nutrition on puberty in the lamb: patterns of tonic luteinizing hormone (LH) secretion and competency of the LH surge system. Endocrinology 116 375-381. (https://doi.org/10.1210/endo-116-1-375)

Foster DL, Ryan KD \& Papkoff H 1984 Hourly administration of luteinizing hormone induces ovulation in prepubertal female sheep. Endocrinology 115 1179-1185. (https://doi.org/10.1210/endo-115-3-1179)

Franceschini I, Lomet D, Cateau M, Delsol G, Tillet Y \& Caraty A 2006 Kisspeptin immunoreactive cells of the ovine preoptic area and arcuate nucleus co-express estrogen receptor alpha. Neuroscience Letters 401 225-230. (https://doi.org/10.1016/j.neulet.2006.03.039)

Fraser GL, Hoveyda HR, Clarke IJ, Ramaswamy S, Plant TM, Rose C \& Millar RP 2015 The NK3 receptor antagonist ESN364 interrupts pulsatile LH secretion and moderates levels of ovarian hormones throughout the menstrual cycle. Endocrinology 156 4214-4225. (https://doi. org/10.1210/en.2015-1409)

Gallegos-Sanchez J, Delaleu B, Caraty A, Malpaux B \& Thiery JC 1997 Estradiol acts locally within the retrochiasmatic area to inhibit pulsatile luteinizing-hormone release in the female sheep during anestrus. Biology of Reproduction 56 1544-1549. (https://doi.org/10.1095/ biolreprod56.6.1544)

Gayrard V, Thiery JC, Thibault J \& Tillet Y 1995 Efferent projections from the retrochiasmatic area to the median eminence and to the pars nervosa of the hypophysis with special reference to the A15 dopaminergic cell group in the sheep. Cell and Tissue Research 281 561-567. (https://doi. org/10.1007/BF00417874)

Gianetti E, Tusset C, Noel SD, Au MG, Dwyer AA, Hughes VA, Abreu AP, Carroll J, Trarbach E, Silveira LF et al. 2010 TAC3/TACR3 mutations reveal preferential activation of gonadotropin-releasing hormone release by neurokinin B in neonatal life followed by reversal in adulthood. Journal of Clinical Endocrinology and Metabolism 95 2857-2867. (https://doi.org/10.1210/jc.2009-2320)

Goodman RL 2015 Neuroendocrine cintrol of gonadotropin secretion: comparative aspects. In Knobil and Neill's Physiology of Reproduction, 4th ed., Elsevier, Amsterdam pp 1537-1574.

Goodman RL \& Karsch FJ 1981 The hypothalmic pulse generator: a key determinant of reproductive cycles in sheep. In Biological Clocks in Seasonal Reproductive Cycles, John Wright \& Sons Ltd., Bristol, UK pp 223-236.

Goodman RL \& Inskeep EK 2006 Neuroendocrine control of the ovarian cycle of the sheep. In Knobil and Neill's Physiology of Reproduction, 3rd ed., Elsevier, Amsterdam pp 2389-2447.

Goodman RL \& Inskeep EK 2015 Control of the ovarian cycle of the sheep. In Knobil and Neill's Physiology of Reproduction, 4th ed., Elsevier, Amsterdam pp 1259-1305.

Goodman RL, Bittman EL, Foster DL \& Karsch FJ 1982 Alterations in the control of luteinizing hormone pulse frequency underlie the seasonal variation in estradiol negative feedback in the ewe. Biology of Reproduction 27 580-589. (https://doi.org/10.1095/biolreprod27.3.580) Goodman RL, Parfitt DB, Evans NP, Dahl GE \& Karsch FJ 1995 Endogenous opioid peptides control the amplitude and shape of gonadotropinreleasing hormone pulses in the ewe. Endocrinology 136 2412-2420. (https://doi.org/10.1210/endo.136.6.7750462) 
Goodman RL, Gibson M, Skinner DC \& Lehman MN 2002 Neuroendocrine control of pulsatile $\mathrm{GnRH}$ secretion during the ovarian cycle: evidence from the ewe. Reproduction Supplement 59 41-56.

Goodman RL, Coolen LM, Anderson GM, Hardy SL, Valent M, Connors JM, Fitzgerald ME \& Lehman MN 2004 Evidence that dynorphin plays a major role in mediating progesterone negative feedback on gonadotropinreleasing hormone neurons in sheep. Endocrinology 145 2959-2967. (https://doi.org/10.1210/en.2003-1305)

Goodman RL, Lehman MN, Smith JT, Coolen LM, de Oliveira CV, Jafarzadehshirazi MR, Pereira A, Iqbal J, Caraty A, Ciofi P et al. 2007 Kisspeptin neurons in the arcuate nucleus of the ewe express both dynorphin A and neurokinin B. Endocrinology 148 5752-5760. (https:// doi.org/10.1210/en.2007-0961)

Goodman RL, Jansen HT, Billings HJ, Coolen LM \& Lehman MN 2010 Neural systems mediating seasonal breeding in the ewe. Journal of Neuroendocrinology 22 674-681. (https://doi.org/10.1111/j.13652826.2010.02014.x)

Goodman RL, Holaskova I, Nestor CC, Connors JM, Billings HJ, Valent M, Lehman MN \& Hileman SM 2011 Evidence that the arcuate nucleus is an important site of progesterone negative feedback in the ewe. Endocrinology 152 3451-3460. (https://doi.org/10.1210/en.2011-0195)

Goodman RL, Hileman SM, Nestor CC, Porter KL, Connors JM, Hardy S, Millar R, Cernea M, Coolen LM \& Lehman MN 2013 Kisspeptin, neurokinin $\mathrm{B}$, and dynorphin act in the arcuate nucleus to control activity of the GnRH pulse generator in ewes. Endocrinology 154 4259-4269. (https://doi.org/10.1210/en.2013-1331)

Goodman RL, Coolen LM \& Lehman MN 2014 A role for neurokinin B in pulsatile GnRH secretion in the ewe. Neuroendocrinology 99 18-32. (https://doi.org/10.1159/000355285)

Goodman RL, Coolen LM \& Lehman MN 2015 Unraveling the mechanism of action of the GnRH pulse generator: a possible role for kisspeptin/ neurokinin B/dynorphin (KNDy) neurons. In Cellular Endocrinology in Health and Disease, Elsevier, Amsterdam pp 133-152.

Goodman RL, Maltby MJ, Millar RP, Hileman SM, Nestor CC, Whited B, Tseng AS, Coolen LM \& Lehman MN 2012 Evidence that dopamine acts via kisspeptin to hold GnRH pulse frequency in check in anestrous ewes. Endocrinology 153 5918-5927. (https://doi.org/10.1210/en.2012-1611)

Goodman RL, Ohkura S, Okamura H, Coolen LM \& Lehman MN 2018 KNDy hypothesis for generation of $\mathrm{GnRH}$ pulses: evidence from sheep and goats. In The GnRH Neuron and its Control, John Wiley \& Sons, Chichester pp 289-324.

Grachev P, Li XF, Lin YS, Hu MH, Elsamani L, Paterson SJ, Millar RP, Lightman SL \& O'Byrne KT 2012 GPR54-dependent stimulation of luteinizing hormone secretion by neurokinin B in prepubertal rats. PLoS ONE 7 e44344. (https://doi.org/10.1371/journal.pone.0044344)

Hakansson ML, Brown H, Ghilardi N, Skoda RC \& Meister B 1998 Leptin receptor immunoreactivity in chemically defined target neurons of the hypothalamus. Journal of Neuroscience 18 559-572. (https://doi. org/10.1523/JNEUROSCI.18-01-00559.1998)

Hardy SL, Anderson GM, Valent M, Connors JM \& Goodman RL 2003 Evidence that estrogen receptor alpha, but not beta, mediates seasonal changes in the response of the ovine retrochiasmatic area to estradiol. Biology of Reproduction 68 846-852. (https://doi.org/10.1095/ biolreprod.102.010215)

Havern RL, Whisnant CS \& Goodman RL 1994 Dopaminergic structures in the ovine hypothalamus mediating estradiol negative feedback in anestrous ewes. Endocrinology 134 1905-1914. (https://doi. org/10.1210/endo.134.4.7907976)

Hazlerigg DG \& Simonneaux V 2015 Seasonal regulation of reproduction in mammals. In Knobil and Neill's Physiology of Reproduction, 4th ed., Elsevier, Amsterdam pp 1575-1604.

Henry BA, Goding JW, Tilbrook AJ, Dunshea FR \& Clarke IJ 2001 Intracerebroventricular infusion of leptin elevates the secretion of luteinising hormone without affecting food intake in long-term food-restricted sheep, but increases growth hormone irrespective of bodyweight. Journal of Endocrinology 168 67-77. (https://doi. org/10.1677/joe.0.1680067)

Herbison AE, Robinson JE \& Skinner DC 1993 Distribution of estrogen receptor-immunoreactive cells in the preoptic area of the ewe: colocalization with glutamic acid decarboxylase but not luteinizing hormone-releasing hormone. Neuroendocrinology 57 751-759. (https:// doi.org/10.1159/000126433)
Horton RJ, Cummins JT \& Clarke IJ 1987 Naloxone evokes large-amplitude $\mathrm{GnRH}$ pulses in luteal-phase ewes. Journal of Reproduction and Fertility 81 277-286. (https://doi.org/10.1530/jrf.0.0810277)

Huffman LJ, Inskeep EK \& Goodman RL 1987 Changes in episodic luteinizing hormone secretion leading to puberty in the lamb. Biology of Reproduction 37 755-761. (https://doi.org/10.1095/biolreprod37.4.755)

I'Anson H, Manning JM, Herbosa CG, Pelt J, Friedman CR, Wood RI, Bucholtz DC \& Foster DL 2000 Central inhibition of gonadotropinreleasing hormone secretion in the growth-restricted hypogonadotropic female sheep. Endocrinology 141 520-527. (https://doi.org/10.1210/ endo.141.2.7308)

Karsch FJ 1987 Central actions of ovarian steroids in the feedback regulation of pulsatile secretion of luteinizing hormone. Annual Review of Physiology 49 365-382. (https://doi.org/10.1146/annurev. ph.49.030187.002053)

Karsch FJ, Legan SJ, Hauger RL \& Foster DL 1977 Negative feedback action of progesterone on tonic luteinizing hormone secretion in the ewe: dependence on the ovaries. Endocrinology 101 800-806. (https:// doi.org/10.1210/endo-101-3-800)

Karsch FJ, Goodman RL \& Legan SJ 1980 Feedback basis of seasonal breeding: test of an hypothesis. Journal of Reproduction and Fertility $\mathbf{5 8}$ 521-535. (https://doi.org/10.1530/jrf.0.0580521)

Keen KL, Wegner FH, Bloom SR, Ghatei MA \& Terasawa E 2008 An increase in kisspeptin-54 release occurs with the pubertal increase in luteinizing hormone-releasing hormone- 1 release in the stalk-median eminence of female rhesus monkeys in vivo. Endocrinology 149 4151-4157. (https:// doi.org/10.1210/en.2008-0231)

Legan SJ, Karsch FJ \& Foster DL 1977 The endocrine control of seasonal reproductive function in the ewe: a marked change in response to the negative feedback action of estradiol on luteinizing hormone secretion. Endocrinology 101 818-824. (https://doi.org/10.1210/endo-101-3-818)

Lehman MN \& Karsch FJ 1993 Do gonadotropin-releasing hormone, tyrosine hydroxylase-, and beta-endorphin-immunoreactive neurons contain estrogen receptors? A double-label immunocytochemical study in the Suffolk ewe. Endocrinology 133 887-895. (https://doi. org/10.1210/endo.133.2.8102098)

Lehman MN, Durham DM, Jansen HT, Adrian B \& Goodman RL 1996 Dopaminergic A14/A15 neurons are activated during estradiol negative feedback in anestrous, but not breeding season, ewes. Endocrinology 137 4443-4450. (https://doi.org/10.1210/endo.137.10.8828506)

Lehman MN, Coolen LM \& Goodman RL 2010 Minireview: kisspeptin/ neurokinin B/dynorphin (KNDy) cells of the arcuate nucleus: a central node in the control of gonadotropin-releasing hormone secretion. Endocrinology 151 3479-3489. (https://doi.org/10.1210/en.2010-0022)

Li Q, Millar RP, Clarke IJ \& Smith JT 2015 Evidence that neurokinin B controls basal gonadotropin-releasing hormone secretion but is not critical for estrogen-positive feedback in sheep. Neuroendocrinology 101 161-174. (https://doi.org/10.1159/000377702)

Lopez JA, Bedenbaugh MN, McCosh RB, Weems PW, Meadows LJ, Wisman B, Coolen LM, Goodman RL \& Hileman SM 2016 Does dynorphin play a role in the onset of puberty in female sheep? Journal of Neuroendocrinology 28 1-11. (https://doi.org/10.1111/jne.12445)

Louis GW, Greenwald-Yarnell M, Phillips R, Coolen LM, Lehman MN \& Myers MG Jr 2011 Molecular mapping of the neural pathways linking leptin to the neuroendocrine reproductive axis. Endocrinology 152 2302-2310. (https://doi.org/10.1210/en.2011-0096)

Manfredi-Lozano M, Roa J, Ruiz-Pino F, Piet R, Garcia-Galiano D, Pineda R, Zamora A, Leon S, Sanchez-Garrido MA, Romero-Ruiz A et al. 2016 Defining a novel leptin-melanocortin-kisspeptin pathway involved in the metabolic control of puberty. Molecular Metabolism 5 844-857. (https://doi.org/10.1016/j.molmet.2016.08.003)

Marshall JC \& Kelch RP 1986 Gonadotropin-releasing hormone: role of pulsatile secretion in the regulation of reproduction. New England Journal of Medicine 315 1459-1468. (https://doi.org/10.1056/ NEJM198612043152306)

McCosh RB, Szeligo BM, Bedenbaugh MN, Lopez JA, Hardy SL, Hileman SM, Lehman MN \& Goodman RL 2017 Evidence that endogenous somatostatin inhibits episodic, but not surge, secretion of $\mathrm{LH}$ in female sheep. Endocrinology 158 1827-1837. (https://doi. org/10.1210/en.2017-00075)

McManus CJ, Goodman RL, Llanza NV, Valent M, Dobbins AB, Connors JM \& Hileman SM 2005 Inhibition of luteinizing hormone secretion by 
localized administration of estrogen, but not dihydrotestosterone, is enhanced in the ventromedial hypothalamus during feed restriction in the young wether. Biology of Reproduction 73 781-789. (https://doi. org/10.1095/biolreprod.105.042275)

McShane TM, May T, Miner JL \& Keisler DH 1992 Central actions of neuropeptide-Y may provide a neuromodulatory link between nutrition and reproduction. Biology of Reproduction 46 1151-1157. (https://doi. org/10.1095/biolreprod46.6.1151)

McShane TM, Petersen SL, McCrone S \& Keisler DH 1993 Influence of food restriction on neuropeptide-Y, proopiomelanocortin, and luteinizing hormone-releasing hormone gene expression in sheep hypothalami. Biology of Reproduction 49 831-839. (https://doi.org/10.1095/ biolreprod49.4.831)

Merkley CM, Porter KL, Coolen LM, Hileman SM, Billings HJ, Drews S, Goodman RL \& Lehman MN 2012 KNDy (Kisspeptin/Neurokinin B/ Dynorphin) neurons are activated during both pulsatile and surge secretion of LH in the ewe. Endocrinology 153 5406-5415. (https://doi. org/10.1210/en.2012-1357)

Merkley CM, Coolen LM, Goodman RL \& Lehman MN 2015 Evidence for changes in numbers of synaptic inputs onto KNDy and GnRH neurones during the preovulatory LH surge in the ewe. Journal of Neuroendocrinology 27 624-635. (https://doi.org/10.1111/jne.12293)

Moenter SM, Brand RC \& Karsch FJ 1992a Dynamics of gonadotropinreleasing hormone $(\mathrm{GnRH})$ secretion during the $\mathrm{GnRH}$ surge: insights into the mechanism of GnRH surge induction. Endocrinology 130 2978-2984. (https://doi.org/10.1210/endo.130.5.1572305)

Moenter SM, Brand RM, Midgley AR \& Karsch FJ 1992b Dynamics of gonadotropin-releasing hormone release during a pulse. Endocrinology 130 503-510. (https://doi.org/10.1210/endo.130.1.1727719)

Nagatani S, Zeng Y, Keisler DH, Foster DL \& Jaffe CA 2000 Leptin regulates pulsatile luteinizing hormone and growth hormone secretion in the sheep. Endocrinology 141 3965-3975. (https://doi.org/10.1210/ endo.141.11.7762)

Navarro VM, Gottsch ML, Chavkin C, Okamura H, Clifton DK \& Steiner RA 2009 Regulation of gonadotropin-releasing hormone secretion by kisspeptin/dynorphin/neurokinin B neurons in the arcuate nucleus of the mouse. Journal of Neuroscience 29 11859-11866. (https://doi. org/10.1523/JNEUROSCI.1569-09.2009)

Navarro VM, Castellano JM, McConkey SM, Pineda R, Ruiz-Pino F, Pinilla L, Clifton DK, Tena-Sempere M \& Steiner RA 2011a Interactions between kisspeptin and neurokinin $\mathrm{B}$ in the control of $\mathrm{GnRH}$ secretion in the female rat. American Journal of Physiology: Endocrinology and Metabolism 300 E202-E210. (https://doi.org/10.1152/ajpendo.00517.2010)

Navarro VM, Gottsch ML, Wu M, Garcia-Galiano D, Hobbs SJ, Bosch MA, Pinilla L, Clifton DK, Dearth A, Ronnekleiv OK et al. 2011b Regulation of NKB pathways and their roles in the control of Kiss1 neurons in the arcuate nucleus of the male mouse. Endocrinology 152 4265-4275. (https://doi.org/10.1210/en.2011-1143)

Nestor CC, Briscoe AM, Davis SM, Valent M, Goodman RL \& Hileman SM 2012 Evidence of a role for kisspeptin and neurokinin B in puberty of female sheep. Endocrinology 153 2756-2765. (https://doi.org/10.1210/ en.2011-2009)

Nestor CC, Cheng G, Nesselrod GL, Valent M, Connors JM, Hileman SM, Coolen LM, Lehman MN \& Goodman RL 2013 Evidence that orphanin FQ mediates progesterone negative feedback in the ewe. Endocrinology 154 4249-4258. (https://doi.org/10.1210/en.2013-1274)

Nieto CA, Ferguson MB, Macleay CA, Briegel JR, Wood DA, Martin GB \& Thompson AN 2013 Ewe lambs with higher breeding values for growth achieve higher reproductive performance when mated at age 8 months. Theriogenology $80427-435$. (https://doi.org/10.1016/j. theriogenology.2013.05.004)

Oakley AE, Breen KM, Clarke IJ, Karsch FJ, Wagenmaker ER \& Tilbrook AJ 2009a Cortisol reduces gonadotropin-releasing hormone pulse frequency in follicular phase ewes: influence of ovarian steroids. Endocrinology 150 341-349. (https://doi.org/10.1210/en.2008-0587)

Oakley AE, Breen KM, Tilbrook AJ, Wagenmaker ER \& Karsch FJ $2009 \mathrm{~b}$ Role of estradiol in cortisol-induced reduction of luteinizing hormone pulse frequency. Endocrinology 150 2775-2782. (https://doi. org/10.1210/en.2008-1754)

Ojeda SR, Aguado LI \& Smith S 1983 Neuroendocrine mechanisms controlling the onset of female puberty: the rat as a model. Neuroendocrinology 37 306-313. (https://doi.org/10.1159/000123565)
Okamura H, Tsukamura H, Ohkura S, Uenoyama Y, Wakabayashi $\mathrm{Y}$ \& Maeda K 2013 Kisspeptin and GnRH pulse generation. Advances in Experimental Medicine and Biology 784 297-323. (https://doi. org/10.1007/978-1-4614-6199-9_14)

Padilla SL, Qiu J, Nestor CC, Žhang C, Smith AW, Whiddon BB, Ronnekleiv OK, Kelly MJ \& Palmiter RD 2017 AgRP to Kiss1 neuron signaling links nutritional state and fertility. PNAS 114 2413-2418. (https://doi.org/10.1073/pnas.1621065114)

Papargiris MM, Rivalland ET, Clarke IJ, Smith JT, Pereira A \& Tilbrook AJ 2011 Evidence that RF-amide related peptide- 3 is not a mediator of the inhibitory effects of psychosocial stress on gonadotrophin secretion in ovariectomised ewes. Journal of Neuroendocrinology 23 208-215. (https://doi.org/10.1111/j.1365-2826.2010.02094.x)

Polkowska J, Cieslak M, Wankowska M \& Wojcik-Gladysz A 2015 The effect of short fasting on the hypothalamic neuronal system of kisspeptin in peripubertal female lambs. Animal Reproduction Science 159 184-190. (https://doi.org/10.1016/j.anireprosci.2015.06.016)

Polkowska J, Wojcik-Gladysz A, Chmielewska N \& Wankowska M 2017 Expression of kisspeptin protein in hypothalamus and $\mathrm{LH}$ profile of growing female lambs. Reproduction, Fertility and Development 30 609-618. (https://doi.org/10.071/RD17018)

Pompolo S, Rawson JA \& Clarke IJ 2001 Projections from the arcuate/ ventromedial region of the hypothalamus to the preoptic area and bed nucleus of stria terminalis in the brain of the ewe; lack of direct input to gonadotropin-releasing hormone neurons. Brain Research 904 1-12. (https://doi.org/10.1016/S0006-8993(01)02372-1)

Prasad BM, Conover CD, Sarkar DK, Rabii J \& Advis JP 1993 Feed restriction in prepubertal lambs: effect on puberty onset and on in vivo release of luteinizing-hormone-releasing hormone, neuropeptide $\mathrm{Y}$ and beta-endorphin from the posterior-lateral median eminence. Neuroendocrinology 57 1171-1181. (https://doi. org/10.1159/000126484)

Ralph CR, Lehman MN, Goodman RL \& Tilbrook AJ 2016 Impact of psychosocial stress on gonadotrophins and sexual behaviour in females: role for cortisol? Reproduction 152 R1-R14. (https://doi.org/10.1530/ REP-15-0604)

Ramaswamy S, Seminara SB, Pohl CR, DiPietro MJ, Crowley WF Jr \& Plant TM 2007 Effect of continuous intravenous administration of human metastin 45-54 on the neuroendocrine activity of the hypothalamicpituitary-testicular axis in the adult male rhesus monkey (Macaca mulatta). Endocrinology 148 3364-3370. (https://doi.org/10.1210/ en.2007-0207)

Ramaswamy S, Seminara SB \& Plant TM 2011 Evidence from the agonadal juvenile male rhesus monkey (Macaca mulatta) for the view that the action of neurokinin B to trigger gonadotropin-releasing hormone release is upstream from the kisspeptin receptor. Neuroendocrinology 94 237-245. (https://doi.org/10.1159/000329045)

Rance NE, Krajewski SJ, Smith MA, Cholanian M \& Dacks PA 2010 Neurokinin B and the hypothalamic regulation of reproduction. Brain Research 1364 116-128. (https://doi.org/10.1016/j. brainres.2010.08.059)

Redmond JS, Baez-Sandoval GM, Spell KM, Spencer TE, Lents CA, Williams GL \& Amstalden M 2011a Developmental changes in hypothalamic Kiss1 expression during activation of the pulsatile release of luteinising hormone in maturing ewe lambs. Journal of Neuroendocrinology 23 815-822. (https://doi.org/10.1111/j.13652826.2011.02177.x)

Redmond JS, Macedo GG, Velez IC, Caraty A, Williams GL \& Amstalden M $2011 b$ Kisspeptin activates the hypothalamic-adenohypophysealgonadal axis in prepubertal ewe lambs. Reproduction 141 541-548. (https://doi.org/10.1530/REP-10-0467)

Roseweir AK, Kauffman AS, Smith JT, Guerriero KA, Morgan K, PieleckaFortuna J, Pineda R, Gottsch ML, Tena-Sempere M, Moenter SM et al. 2009 Discovery of potent kisspeptin antagonists delineate physiological mechanisms of gonadotropin regulation. Journal of Neuroscience 29 3920-3929. (https://doi.org/10.1523/JNEUROSCI.5740-08.2009)

Sari IP, Rao A, Smith JT, Tilbrook AJ \& Clarke IJ 2009 Effect of RF-amiderelated peptide- 3 on luteinizing hormone and follicle-stimulating hormone synthesis and secretion in ovine pituitary gonadotropes. Endocrinology 150 5549-5556. (https://doi.org/10.1210/en.2009-0775) Seminara SB, Messager S, Chatzidaki EE, Thresher RR, Acierno JS Jr, Shagoury JK, Bo-Abbas Y, Kuohung W, Schwinof KM, Hendrick AG et al. 
2003 The GPR54 gene as a regulator of puberty. New England Journal of Medicine 349 1614-1627. (https://doi.org/10.1056/NEJMoa035322)

Singh SR, Hileman SM, Connors JM, McManus CJ, Coolen LM, Lehman MN \& Goodman RL 2009 Estradiol negative feedback regulation by glutamatergic afferents to A15 dopaminergic neurons: variation with season. Endocrinology 150 4663-4671. (https://doi.org/10.1210/ en.2009-0432)

Skinner DC, Evans NP, Delaleu B, Goodman RL, Bouchard P \& Caraty A 1998 The negative feedback actions of progesterone on gonadotropinreleasing hormone secretion are transduced by the classical progesterone receptor. PNAS 95 10978-10983. (https://doi.org/10.1073/ pnas.95.18.10978)

Smith JT, Clay CM, Caraty A \& Clarke IJ 2007 KiSS-1 messenger ribonucleic acid expression in the hypothalamus of the ewe is regulated by sex steroids and season. Endocrinology 148 1150-1157. (https://doi. org/10.1210/en.2006-1435)

Smith JT, Coolen LM, Kriegsfeld LJ, Sari IP, Jaafarzadehshirazi MR, Maltby M, Bateman K, Goodman RL, Tilbrook AJ, Ubuka T et al. 2008 Variation in kisspeptin and RFamide-related peptide (RFRP) expression and terminal connections to gonadotropin-releasing hormone neurons in the brain: a novel medium for seasonal breeding in the sheep. Endocrinology 149 5770-5782. (https://doi.org/10.1210/en.2008-0581)

Smith JT, Li Q, Pereira A \& Clarke IJ 2009 Kisspeptin neurons in the ovine arcuate nucleus and preoptic area are involved in the preovulatory luteinizing hormone surge. Endocrinology 150 5530-5538. (https://doi. org/10.1210/en.2009-0712)

Smith JT, Li Q, Yap KS, Shahab M, Roseweir AK, Millar RP \& Clarke IJ 2011 Kisspeptin is essential for the full preovulatory LH surge and stimulates $\mathrm{GnRH}$ release from the isolated ovine median eminence. Endocrinology 152 1001-1012. (https://doi.org/10.1210/en.2010-1225)

Smith JT, Young IR, Veldhuis JD \& Clarke IJ 2012 Gonadotropin-inhibitory hormone $(\mathrm{GnlH})$ secretion into the ovine hypophyseal portal system. Endocrinology 153 3368-3375. (https://doi.org/10.1210/en.2012-1088)

Thiery JC, Martin GB, Tillet Y, Caldani M, Quentin M, Jamain C \& Ravault JP 1989 Role of hypothalamic catecholamines in the regulation of luteinizing hormone and prolactin secretion in the ewe during seasonal anestrus. Neuroendocrinology 49 80-87. (https://doi. org/10.1159/000125094)

Thiery JC, Gayrard V, Le Corre S, Viguie C, Martin GB, Chemineau P \& Malpaux B 1995 Dopaminergic control of LH secretion by the A15 nucleus in anoestrous ewes. Journal of Reproduction and Fertility, Supplement 49 285-296.

Topaloglu AK, Reimann F, Guclu M, Yalin AS, Kotan LD, Porter KM, Serin A, Mungan NO, Cook JR, Ozbek MN et al. 2009 TAC3 and TACR3 mutations in familial hypogonadotropic hypogonadism reveal a key role for Neurokinin B in the central control of reproduction. Nature Genetics 41 354-358. (https://doi.org/10.1038/ng.306)

Topaloglu AK, Tello JA, Kotan LD, Ozbek MN, Yilmaz MB, Erdogan S, Gurbuz F, Temiz F, Millar RP \& Yuksel B 2012 Inactivating KISS1 mutation and hypogonadotropic hypogonadism. New England Journal of Medicine 366 629-635. (https://doi.org/10.1056/NEJMoa1111184)

Wagenmaker ER, Breen KM, Oakley AE, Tilbrook AJ \& Karsch FJ 2009 Psychosocial stress inhibits amplitude of gonadotropin-releasing hormone pulses independent of cortisol action on the type II glucocorticoid receptor. Endocrinology 150 762-769. (https://doi. org/10.1210/en.2008-0757)

Wakabayashi Y, Nakada T, Murata K, Ohkura S, Mogi K, Navarro VM, Clifton DK, Mori Y, Tsukamura H, Maeda K et al. 2010 Neurokinin $\mathrm{B}$ and dynorphin $\mathrm{A}$ in kisspeptin neurons of the arcuate nucleus participate in generation of periodic oscillation of neural activity driving pulsatile gonadotropin-releasing hormone secretion in the goat. Journal of Neuroscience 30 3124-3132. (https://doi.org/10.1523/ JNEUROSCI.5848-09.2010)
Walsh JP \& Clarke IJ 1998 Blockade of the oestrogen-induced luteinizing hormone surge in ovariectomized ewes by a highly selective opioid mureceptor agonist: evidence for site of action. Neuroendocrinology 67 164-170. (https://doi.org/10.1159/000054311)

Wang R, Kuang M, Nie H, Bai W, Sun L, Wang F, Mao D \& Wang Z 2016 Impact of food restriction on the expression of the adiponectin system and genes in the hypothalamic-pituitary-ovarian axis of pre-pubertal ewes. Reproduction in Domestic Animals 51 657-664. (https://doi. org/10.1111/rda.12727)

Weems PW, Goodman RL \& Lehman MN 2015 Neural mechanisms controlling seasonal reproduction: principles derived from the sheep model and its comparison with hamsters. Frontiers in Neuroendocrinology 37 43-51. (https://doi.org/10.1016/j.yfrne.2014.12.002)

Weems PW, Coolen LM, Hileman SM, Hardy S, McCosh RB, Goodman RL \& Lehman MN 2016a Kappa opioid receptors are internalized in arcuate KNDy cells during GnRH pulse termination in the ewe. Neuroscience Meeting Planner Abstr. 60.04.

Weems PW, Witty CF, Amstalden M, Coolen LM, Goodman RL \& Lehman MN 2016b kappa-opioid receptor is colocalized in $\mathrm{GnRH}$ and KNDy cells in the female ovine and rat brain. Endocrinology 157 2367-2379. (https://doi.org/10.1210/en.2015-1763)

Weems P, Smith J, Clarke IJ, Coolen LM, Goodman RL \& Lehman MN $2017 a$ Effects of season and estradiol on KNDy neuron peptides, colocalization with D2 dopamine receptors, and dopaminergic inputs in the ewe. Endocrinology 158 831-841. (https://doi.org/10.1210/en.20161830)

Weems PW, Coolen LM, Hileman SM, Hardy S, McCosh RB, Goodman RL \& Lehman MN 2017b Kappa opioid receptors are internalized in $\mathrm{MBH}$ $\mathrm{GnRH}$ cells during $\mathrm{GnRH}$ pulse termination. Endocrine Reviews 38 Abstr. 472 .

Weems PW, Lehman MN, Coolen LM \& Goodman RL 2018 The roles of neurokinins and endogenous opioid peptides in control of pulsatile $\mathrm{LH}$ secretion. Vitamins and Hormones 107 89-135. (https://doi.org/10.1016/ bs.vh.2018.01.011)

Weesner GD \& Malven PV 1990 Intracerebral immunoneutralization of beta-endorphin and met-enkephalin disinhibits release of pituitary luteinizing hormone in sheep. Neuroendocrinology 52 382-388. (https://doi.org/10.1159/000125609)

Whisnant CS \& Goodman RL 1988 Effects of an opioid antagonist on pulsatile luteinizing hormone secretion in the ewe vary with changes in steroid negative feedback. Biology of Reproduction 39 1032-1038. (https://doi.org/10.1095/biolreprod39.5.1032)

Whisnant CS \& Goodman RL 1994 Effect of anterior hypothalamic deafferentation on the negative feedback of gonadal steroids on luteinizing hormone pulse frequency in the ewe. Domestic Animal Endocrinology 11 151-159. (https://doi.org/10.1016/0739-7240(94)90023-X)

Wildt L, Marshall G \& Knobil E 1980 Experimental induction of puberty in the infantile female rhesus monkey. Science 207 1373-1375. (https:// doi.org/10.1126/science.6986658)

Yang K, Haynes NB, Lamming GE \& Brooks AN 1988 Ovarian steroid hormone involvement in endogenous opioid modulation of $\mathrm{LH}$ secretion in mature ewes during the breeding and non-breeding seasons. Journal of Reproduction and Fertility 83 129-139. (https://doi.org/10.1530/ jrf.0.0830129)

Received 7 March 2018

First decision 3 April 2018

Revised manuscript received 18 May 2018

Accepted 7 June 2018 